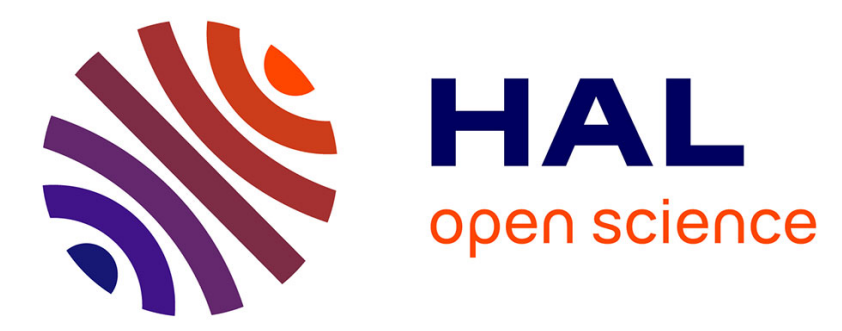

\title{
Novel solar PV/Thermal collector design for the enhancement of thermal and electrical performances
}

Oussama Rejeb, Leon Gaillard, Stéphanie Giroux-Julien, Chaouki Ghenai, Abdelmajid Jemni, Maamar Bettayeb, Christophe Menezo

\section{To cite this version:}

Oussama Rejeb, Leon Gaillard, Stéphanie Giroux-Julien, Chaouki Ghenai, Abdelmajid Jemni, et al.. Novel solar PV/Thermal collector design for the enhancement of thermal and electrical performances. Renewable Energy, 2020, 146, pp.610 - 627. 10.1016/j.renene.2019.06.158 . hal-03487357

\section{HAL Id: hal-03487357 https://hal.science/hal-03487357}

Submitted on 20 Dec 2021

HAL is a multi-disciplinary open access archive for the deposit and dissemination of scientific research documents, whether they are published or not. The documents may come from teaching and research institutions in France or abroad, or from public or private research centers.
L'archive ouverte pluridisciplinaire HAL, est destinée au dépôt et à la diffusion de documents scientifiques de niveau recherche, publiés ou non, émanant des établissements d'enseignement et de recherche français ou étrangers, des laboratoires publics ou privés.

\section{(ㄷ)(1) $\$$}

Distributed under a Creative Commons Attribution - NonCommercial| 4.0 International 


\section{Novel Solar PV/Thermal Collector Design for the Enhancement of Thermal and Electrical Performances}

3 Oussama REJEB ${ }^{\mathrm{a}, \mathrm{c}}$, Leon GAILLARD ${ }^{\mathrm{a}}$, Stéphanie GIROUX-JULIEN ${ }^{\mathrm{b}}$, Chaouki GHENAI $^{\mathrm{e}}$, Abdelmajid

a. Université Savoie Mont Blanc, LOCIE UMR CNRS/USMB 5271, FédESol FR3344, INES Campus Scientifique Savoie Technolac - Bâtiment Hélios, Avenue du Lac Léman, F-73376, Le Bourget-du-Lac, France.

b. Université de Lyon, CETHIL UMR Claude Bernard Lyon 1/CNRS/INSA 5008, FédESol FR3344, Campus LyonTech La Doua, F-69621 Cedex, France.

c. Sustainable Energy Development Reseach Group, Research Institute for Sciences and Engineering (RISE), University of Sharjah, P.O.Box 27272, Sharjah, United Arab Emirates.

d. Université de Monastir, Ecole Nationale d'Ingénieurs de Monastir (ENIM), Laboratoire d'Etudes des Systèmes Thermiques et Energétiques (LESTE), LR99ES31, 5000, Monastir, Tunisie.

e. Department of Sustainable and Renewable Energy Engineering, College of Engineering, University of Sharjah, Sharjah, United Arab Emirates. 


\section{ABSTRACT}

The main objective of this study is to develop a novel photovoltaic thermal collector (PVT) to improve the electrical and thermal efficiencies of the solar collector. The goal is to maximize the electrical power and minimize the thermal losses of the solar panel. A novel photovoltaic thermal collector is designed and tested. The new PVT collector includes: (1) An optical anti-reflective and low-emissivity coating to reduce the radiation losses; (2) A thermal resistance to reduce the conduction losses between the photovoltaic and absorber plate; and (3) A channel heat exchanger to decrease the thermal losses between the solar cells and the cooling fluid. A transient two-dimension multi-physics model for the PVT sheettube and the advanced PVT collector is developed. The state variable variations are predicted by the finite volume method. A comparison between the two considered hybrid collectors in terms of thermal and electrical efficiencies and temperature distribution is performed. Moreover, the impact of arrangement (anti-reflective and low-emissivity coating, thermal resistance between the absorber plate and the cooling fluid, enhanced exchange surface area between the flat plat exchanger and the cooling fluid) on the new PVT collector is studied and analyzed. The simulation results showed clearly the advantages of using this evolution of the PVT collector compared to the basic one. Indeed, this new PVT configuration represents a series of improvements that lead to a lower PV module and higher fluid operating temperatures. Higher electrical and thermal efficiencies for the proposed PVT $(15.4 \%, 73 \%)$ are obtained compared to the basic PVT collector $(13.7 \%, 58 \%)$, respectively under no loss and standard test conditions.

Keywords: Hybrid solar PVT, Back Cooling, Electrical Efficiency, Thermal Efficiency, Novel Collector, Channel Heat Exchanger.

Corresponding Author: Oussama.r009@ hotmail.fr

Tel : +33 695531547. LOCIE UMR CNRS 5271/INES, Campus Scientifique Savoie Technolac - Bâtiment Hélios, Avenue du Lac Léman, F-73376, Le Bourget-du-Lac, France. 
Nomenclature

A

$C_{p}$

E

K

G

$\mathrm{h}$

$\mathrm{Nu}$

$\mathrm{Ra}$

$\operatorname{Pr}$

$\mathrm{Pe}$

$\mathrm{T}$

$m$

Greek

$\beta$

$\rho$

$\delta$

$\varepsilon$

$\eta$

$\tau$
Surface area $\left(\mathrm{m}^{2}\right)$

Specific heat (J/Kg.K)

Electrical power output (W)

Thermal conductivity (W/m.K)

Solar irradiation $\left(\mathrm{W} / \mathrm{m}^{2}\right)$

Heat transfer coefficient (W/m.K)

Nusselt number

Rayleigh number

Prandtl number

Perimeter (m)

Time (s)

Mass flow rate $(\mathrm{Kg} / \mathrm{s})$

PV cell temperature coefficient $\left(\mathrm{K}^{-1}\right)$

Density $\left(\mathrm{Kg} / \mathrm{m}^{3}\right)$

Thickness (m)

Emissivity

Efficiency (\%)

Solar transmission 


\section{Subscripts}

Amb

Ad

Env

Con

Cond

C

Elec

is

in

PV

$\mathrm{Pab}$

Pabu

Pabh

Out

Th

68

wi

69

RMS

70

FVM
Ambient

Adhesive

Environnement

Convection

Conduction

Collector

Electrical

Insulation

Inlet

Photovoltaic module

Absorber plate

Upper half of absorber

Lower half of absorber

Outlet

Thermal

Wind

mean root square deviation

finite volume method 


\section{INTRODUCTION}

76

Solar thermal collectors and photovoltaic panels are recognized as favourable solutions for collecting and transforming solar energy to useful energy due to the abundance and inexhaustibility of the solar resource. A solar thermal (ST) collector is a device that converts solar radiation energy into heat. Due to the photoconversion effect, the photovoltaic module is converting a part of sunlight into electrical energy. Around $80 \%$ of the solar radiation captured by the PV module is not converted, it consequently causes elevation of the operating temperature, which induces a decrease of their efficiency and ageing. Indeed, the PV cells that operate under strong sunlight and high temperature (i.e. in tropical or desert regions or in summer seasons in temperate areas) generally suffer from more efficiency loss [1]. The thermal and electrical cogeneration combined in a photovoltaic thermal collector is an effective way to reduce the loss of collected solar radiation through heat dissipation and to control the PV module temperature. The temperature regulation of photovoltaic panels can be achieved by several methods such as air-cooling, water-cooling, use of heat pipe, phase change materials and thermoelectric cooling. For a configuration of air forced cooling the back side temperature of a PV module is higher than at the front side. Garg et al. [2] studied the influence of cooling the photovoltaic module using natural or forced air. The maximum photovoltaic module obtained is around $49^{\circ} \mathrm{C}$ for the natural circulation mode against $45^{\circ} \mathrm{C}$ found by the forced circulation mode. The water has obviously a better ability to transport heat than air. As a classical configuration, the water flows through a heat exchanger which it placed at the rear surface of the PV module. Several configurations can be found mostly depending on thermal contact between PV and Thermal functions. Such PVT could be uncovered or covered with a glass placed on the front of the collector. A glass cover reduces the thermal losses of the collector but increases the optical losses (reflection, absorption) and consequently reduces the electrical efficiency of the photovoltaic module. A conventional the PVT sheet and tube glazed collector provides a lowest electrical and thermal performance for the same area with respect to the separate conventional PV and Thermal panels. A comparative investigation between a PVT with sheet and tube absorber, a standard photovoltaic module and a traditional ST collector with a sheet and tube absorber, has been performed by Rejeb et al. [3]. $43.51 \%$ and $65.31 \%$ thermal efficiencies were reported, for the covered PVT collector and the covered ST collector both with sheet and tube absorber, respectively. Bergene et al. [4] developed a mathematical model to study the behaviour of a solar photovoltaic thermal sheet and tube collector. They investigated 
the effect of fin size, flow rate and the inlet fluid temperature on the electrical and thermal performance. They noted that for optimized values of these parameters, the overall (thermal + electrical) efficiencies can be reached at $80 \%$. Taoufek et al. [5] carried out a numerical study and experimental validation of an unglazed PVT with a galvanized steel sheet and tube absorber. They reported that the maximal thermal useful heat and the electrical power generated by the PVT collector were $290 \mathrm{~W}$ and $48 \mathrm{~W}$, respectively. Their work was performed under the meteorological conditions of Ghardaia (latitude of $32.29^{\circ} \mathrm{N}$; longitude of $3.41^{\circ} \mathrm{E}$ ) in Algeria. The solar radiation varied between 100- $1020 \mathrm{~W} / \mathrm{m} 2$ from 7:00AM to 19:0PM. Thus, several works focused on the improvement of the performance of PVT. The PVT sheet and tube configuration has to date been the most extensively studied in literature [3-12], despite a relatively low efficiency commonly arising from a poor thermal coupling between the photovoltaic module and the thermal absorber. Furthermore, different works have been carried out to transform the PVT sheet and tube configuration to a more developed PVT structure at lower cost. Sandnes et al. [13] investigated a PVT collector with a polymer flat exchanger absorber. Their hybrid collector consists of cSi solar cells jointed to a polymer heat exchanger (polyphenylenoxide plastics) in order to improve the heat transfer to the cooling fluid. Their results showed that the presence of solar cells on the top of the absorber reduce the absorption about $10 \%$, whereas the presence of an additional glass reduces the optical efficiency by about $5 \%$. A comparative investigation on the photovoltaic thermal collector with straight absorber channels and was carried out by Salem et al. [14] for a $1.0 \mathrm{~L} / \mathrm{min}$ flow rate, a $47.2 \%$ and $34.3 \%$ value of thermal performance for straight channels and helical ones were obtained.

In addition, the integration of phase change materials to regulate their operating temperatures has attracted the attention of several authors [15-18]. Yang et al. [15] have experimentally studied the possibility of integrating phase change materials (PCMs) within a PVT collector. The collector consists of an absorbing plate fixed at the rear of a photovoltaic module. Water tubes are welded to the absorber. A layer of MCP is then placed at the rear of the tubes. A $8.16 \%$ and $6.98 \%$ value of electrical efficiency for PVT with PCM and for PVT were obtained. Other studies have shown that heat transfer inside the PVT collector can be improve by using a porous media [19-20]. Omer el al [19] studied experimentally the performance of PVT using the porous media. Their experiments were performed under the meteorological conditions of Kirkuk (latitude of $35.47^{\circ} \mathrm{N}$; longitude of $44.40^{\circ} \mathrm{E}$ ) in Iraq. The ambient temperature ranged between $25-29{ }^{\circ} \mathrm{C}$, while the solar radiation varied between $580-1000 \mathrm{~W} / \mathrm{m} 2$ from 9:00AM to 16:0PM. The results revealed that the maximum electrical power outputs with porous media is $98 \mathrm{~W}$, while without porous media was $92 \mathrm{~W}$. Also it can be seen that the thermal useful heat power outputs with porous media collector was $860 \mathrm{~W}$, while without porous media was $710 \mathrm{~W}$. 
Other technics such as the combination of water and air as a heat transfer fluid (bi-fluid) in order to extract the heat from the PV module can also lower the PV function operating temperature. A bi-fluid PVT [21-26] collector was designed to generate the electrical power, heating air for buildings or drying applications and for domestic hot water heating. A numerical and experimental study was carried out by Jarimi et al. [21] in order to compared the electrical and thermal performances of PVT for different cooling modes (air, water and combined air/water). They concluded that using bi-fluid provided the best higher electrical and thermal outputs powers compared with the separate use of air or water.

The thermal resistance conduction between the PV cells and the heat absorber exchanger should be minimized. Zondag [27] examined the effect of improving the thermal exchange through the thermal conductance between the photovoltaic module and the absorber sheet varying between $40 \mathrm{~W} / \mathrm{m} . \mathrm{K}$ and 250 $\mathrm{W} / \mathrm{m}$.K. Its review paper showed that a small value leads to an increase of the temperature difference between the PV module and the absorber (by $12^{\circ} \mathrm{C}$ ) and therefore is reducing both, the thermal and electrical efficiencies. Dupeyrat et al. [28] designed a high performance advanced PVT collector with enhancement thermal conductance $(700 \mathrm{~W} / \mathrm{m} . \mathrm{K})$ between the PV module and thermal absorber $(1.2 \mathrm{~mm}$ roll bond aluminium) by laminating the PV cells to absorber directly using EVA resin (Ethylene Vinyl Acetate). A maximum of $87 \%$ overall performance have been achieved.

Like the thermal resistance between the two functions of a PVT collector, the optical efficiency plays an important role in determining the overall thermal and electrical performance. Zondag [27] noted that adding the anti-reflective coating (ARC) to the transparent glazing and encapsulation area can be favourable. Also, they suggest that the use of low emissivity coatings leads to enhancement of the thermal efficiency and a decrease in the electrical performance. Gang [29] examined the impact of using a low emissivity coating, in order to reduce the optical loss in the PVT heat pipe collector. A $\left(270.3 \mathrm{~W} / \mathrm{m}^{2}\right.$, $\left.178.9 \mathrm{~W} / \mathrm{m}^{2}, 284 \mathrm{~W} / \mathrm{m}^{2}\right)$ on the heat gain and $\left(34.8 \mathrm{~W} / \mathrm{m} 2,35.0 \mathrm{~W} / \mathrm{m} 2,36.5 \mathrm{~W} / \mathrm{m}^{2}\right)$ on the electrical power were found for solar selective coating, black pigment coating and no coating on the absorber plate, respectively. Santbergen et al. [30] calculated the effect of a $300 \mathrm{~nm} \mathrm{SnO} 2$ coating on the electrical performance of a PVT collector. A reduction of the emissivity from 0.8 to 0.2 was calculated with a corresponding reduction of the electrical performance from $12.97 \%$ to $11.84 \%$. For the developed lowemissivity coating used by Lämmle et al. [31], a $60 \%$ enhancement of the thermal performance and a $3 \%$ decrease of the electrical performance were observed.

In a methodology point of view, the majority of previous studies on heat transfer governing the PVT collector performance have considered a steady state approach to assess behaviour model. Using the modified Hottel-Whiller model developed by Florschuetz [32], the thermal efficiency can be presented by 
the global thermal loss, mean fluid and ambient temperatures, solar radiation and heat removal factor. This model neglects the thermal mass and thus provides accurate results only with data averaged over a long period. Hence it is unsuitable for studies of thermal and electrical performance under rapidly varying inlet water temperature, wind speed, ambient temperature, or solar radiation fluctuations. Similarly, it is not suitable for achieving control criteria for instantaneous regulation systems. Chow [33] noted that the operation of a PV/T collector is inherently dynamic: the variation of climatic conditions (solar irradiance, wind speed) are transient in nature. A dynamical model is particularly useful in order to investigate in-use behavioural thermal response and energy performances of various collector components. Lumped capacitance models presented the simplest dynamical models that take into account the thermal mass by considering aggregated thermal capacitances. This model can reproduce the observed variations with satisfactory accuracy in the limit of low to moderate thermal inertia.

The mesh-based models [34] (the finite-element, finite-difference, and finite-volume methods) introduce the discretization of the solar collector along the fluid direction. It is then possible to reproduce the fluid temperature profile and, therefore, to calculate the outlet fluid temperature with a higher accuracy. Compared to other discretization methods, the advantage of this method is to ensure the conservation of flows and thus avoid the generation of parasitic sources. It has the advantage of strictly respecting the conservation equations, not only in a global way (compared to finite-difference), but also for each volume of control, this advantage is fully expressed in the case of strongly coupled and nonlinear equations (compared to finite-element).

Although a 1D discretized model can predict the behaviour of collector with a good accuracy, it is not able to predict the spatial distribution of temperature across the whole collector surface. However, a nonhomogeneity of the temperature distribution on a solar PV panel leads to a performance degradation and ageing acceleration. It is therefore very important to understand the temperature distribution inside the photovoltaic module. Moreover, the electrical performance decreases due to the non-uniform solar cell temperature distribution which leads to a reverse saturation current [35] and to problems of mismatch [36]. Furthermore, thermal expansion depends on the temperature of the local cell and the non-uniformity of the cell temperature causes mechanical stress and decreases the lifespan of solar cells [37]. To overcome the limitations associated with one-dimensional models of the PVT systems, the twodimensional models are then essential.

In the above-mentioned literature, a PVT collector that contains all the possible enhancements (antireflective and low-emissivity coating, thermal resistance between the absorber plate and the cooling fluid, the exchange surface area between the flat plat exchanger and the cooling fluid), within a single 
component, has not yet been investigated and examined. The innovation and originality of this study is to develop a two-dimensional approach using the finite volume method (FVM), in order to study the heat transfer mechanisms (heat diffusion, thermal radiation, energy transfer) and the photo-conversion. The choice of a 2D modelling approach allows to tackle the distribution of temperature in the photovoltaic module and to increase the accuracy of the behavioural description in order to guide design decisions. The advanced PVT collector is developed in order to: reduce the optical and thermal losses, maximize the fluid temperature and to minimize the PV module operating temperature effect. Moreover, the impact of the arrangements such as anti-reflective and low-emissivity coating, thermal resistance thermal between the absorber plate and the cooling fluid, enhanced exchange surface area between the flat plat exchanger and the cooling fluid are studied and analysed. Moreover, a comparison between the proposed PVT collector and basic ones is performed in terms of temperature distribution and thermal and electrical performances. In the section 2 the developed mathematical model is introduced. The numerical solution and model validation are presented in section 3 and 4 and the results are presented in section 5.

\section{Mathematical MODEL}

Theoretical models are carried out to examine and investigate the thermal and electrical behaviour for two hybrid PVT collectors (sheet and tube design and advanced channelled configuration). An energy thermal balance model inside the different components of two considered hybrid PVT collectors is established. It is based on the geometric description of the system and the coupling between the conduction heat transfer inside the different layers, convection and radiation exchange inside the collector and the heat exchanges with surroundings (convective and radiation losses) and solar energy conversion to electrical power. Various assumptions have been introduced in order to facilitate the calculations. (i) The solar radiation distribution in the collector is uniform, (ii) The thermo-physical parameters of each solid layer of the collector are considered constant, (iii) Thermal losses on the lateral sides are neglected. (iiii) Ohmic losses in photovoltaic cells are neglected. The governing equations for the different collectors are presented in the following sections.

\subsection{PVT Sheet and Tube Collector}

The proposed solar hybrid PVT sheet and tube without optical coatings is shown in Fig.1. An absorbent sheet is jointed on the PV module rear area using an adhesive layer. The water flows across tubes welding to the absorbent sheet in order to remove the un-useful heat from the PV module, therefore lowering the running PV cells temperature and transferring heat to domestic use. In order to reduce the forward thermal losses of the collector (wind convection and radiation losses) to the surrounding, a glazing is 
placed between the PV module and the ambient air. A back thermal insulation (glass wool) is placed at the rear collector surface in order to decrease the back thermal losses collector.

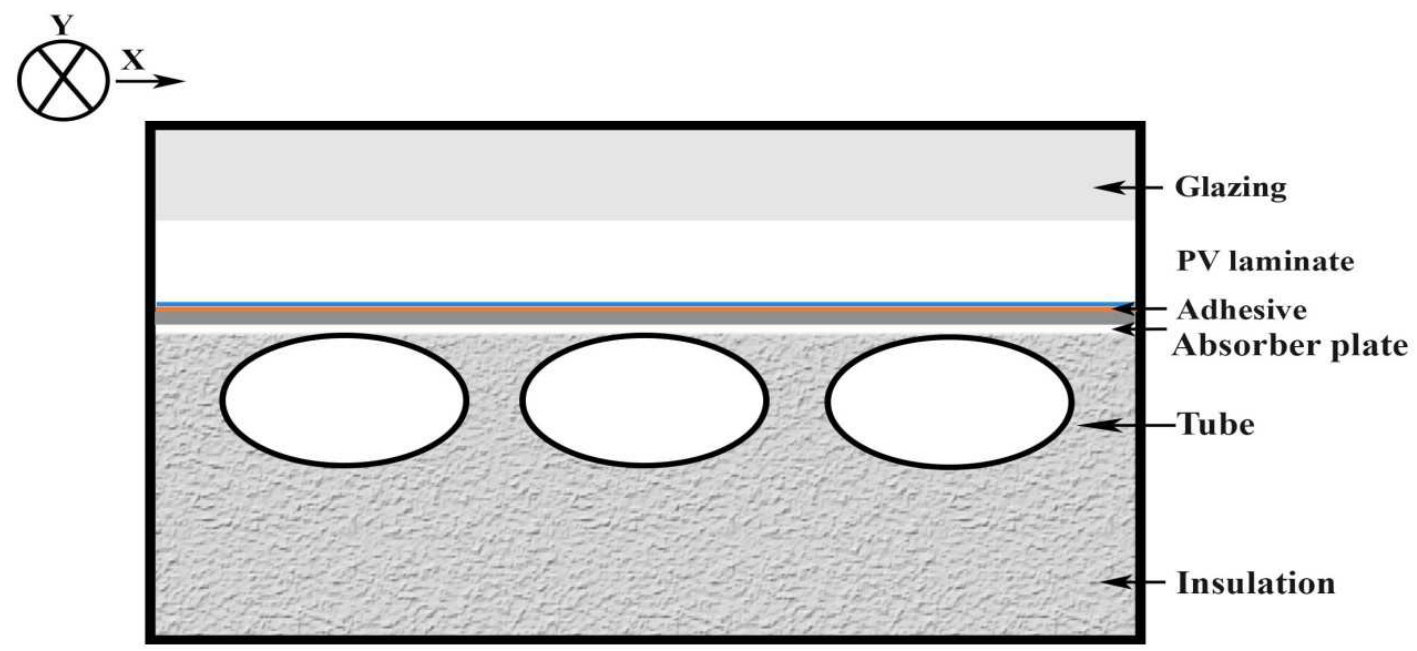

Figure 1: The proposed solar hybrid PVT sheet and tube (baseline) considered in the present study.

The glazing thermal energy balance (Eq. 1) is estimated by considering that the stocked energy by the glazing $\left(\mathrm{m}_{\mathrm{g}} \mathrm{C}_{\mathrm{g}} \frac{\mathrm{dT}_{\mathrm{g}}}{\mathrm{dt}}\right)$ is identical to the sum of the radiation exchange flux $\left(\mathrm{Q}_{\mathrm{ray}, \mathrm{g} \rightarrow \text { env }}\right)$ between the collector and the surroundings (sky), the heat exchange by convection between the collector and the surroundings $\left(Q_{\text {conv,g } \rightarrow a m b}\right)$, the absorbed solar energy by glazing $\left(Q_{\mathrm{in}, \mathrm{g}}\right)$, convective $\left(Q_{\text {conv,g } \rightarrow \mathrm{amb}}\right)$ and the radiation

$242\left(Q_{r a y, p v \rightarrow g}\right)$ heat transfer exchange of the air enclosed in the gap and the conductive flux within the glazing $243\left(Q_{\text {cond,g }}\right)$.

$\mathrm{m}_{\mathrm{g}} \mathrm{C}_{\mathrm{g}} \frac{\mathrm{dT}_{\mathrm{g}}}{\mathrm{dt}}=\mathrm{Q}_{\mathrm{in}, \mathrm{g}}-\mathrm{Q}_{\mathrm{conv}, \mathrm{g} \rightarrow \mathrm{amb}}-\mathrm{Q}_{\mathrm{ray}, \mathrm{g} \rightarrow \mathrm{env}}+\mathrm{Q}_{\mathrm{conv}, \mathrm{pv} \rightarrow \mathrm{g}}+\mathrm{Q}_{\mathrm{ray}, \mathrm{pv} \rightarrow \mathrm{g}}+\mathrm{Q}_{\mathrm{cond}, \mathrm{g}}$

$\mathrm{Q}_{\mathrm{in}, \mathrm{g}}$ is the amount of solar radiation absorbed by the glazing, and is determined by

$$
Q_{\text {in, }}=\alpha_{\mathrm{g}} \mathrm{G}
$$

where, $\mathrm{G}$ is the solar radiation reached by the glazing and $\alpha_{\mathrm{g}}$ is the effective absorptance of glazing. 
$\left(Q_{\text {conv,g } \rightarrow a m b}\right)$ is the wind convection exchange from the glazing to ambient and it is calculated using the

$\left(\mathrm{Q}_{\mathrm{conv}, \mathrm{g} \rightarrow \mathrm{amb}}\right)=\mathrm{A}\left(5.7+3.8 \mathrm{~V}_{\mathrm{wi}}\right)\left(\mathrm{T}_{\mathrm{amb}}-\mathrm{T}_{\mathrm{g}}\right)$ where, $V_{w i}$ is wind speed. $T_{a m b}, T_{g}$ are ambient, glazing temperatures, respectively.

The net infrared radiation exchange $\left(Q_{\text {ray,g } \rightarrow \text { env }}\right)$ from the glazing to the sky can be determined assuming that the sky is a black body with a temperature of $\mathrm{T}_{\text {sky }}$ [39].

$$
\mathrm{Q}_{\text {ray, } \mathrm{g} \rightarrow \text { env }}=A \varepsilon_{\mathrm{g}} \sigma\left(\mathrm{T}_{\mathrm{g}}^{2}+\mathrm{T}_{\text {sky }}^{2}\right)\left(\mathrm{T}_{\mathrm{g}}+\mathrm{T}_{\text {sky }}\right)\left(\mathrm{T}_{\mathrm{g}}-\mathrm{T}_{\text {sky }}\right)
$$

Where $\varepsilon_{\mathrm{g}}$ is the emissivity of glass cover, $\mathrm{T}_{\mathrm{sky}}$ is the sky temperature, and $\sigma$ is the Stefan Boltzmann constant $\left(5.6697 \times 10-8 \mathrm{~W} /\left(\mathrm{m}^{2} \cdot \mathrm{K}^{4}\right)\right)$.

The sky $\left(\mathrm{T}_{\text {sky }}\right)$ temperature is given by the Swinbank formula [40].

$\mathrm{T}_{\text {sky }}=0.0522 * \mathrm{~T}_{\mathrm{amb}}^{1.5}$ gap, can be written as [3].

$$
\begin{aligned}
& \mathrm{Q}_{\text {ray,pv } \rightarrow \mathrm{g}}=\mathrm{A} \frac{\sigma\left(\mathrm{T}_{\mathrm{g}}^{2}+\mathrm{T}_{\mathrm{pv}}^{2}\right)\left(\mathrm{T}_{\mathrm{g}}+\mathrm{T}_{\mathrm{pv}}\right)}{\frac{1}{\varepsilon_{\mathrm{pv}}}+\frac{1}{\varepsilon_{\mathrm{g}}}-1}\left(\mathrm{~T}_{\mathrm{g}}-\mathrm{T}_{\mathrm{pv}}\right) \\
& \mathrm{Q}_{\text {conv }, \mathrm{pv} \rightarrow \mathrm{g}}=\mathrm{A} \frac{\mathrm{Nu}_{\mathrm{a}} \mathrm{k}_{\mathrm{a}}}{\delta_{\mathrm{a}}}\left(\mathrm{T}_{\mathrm{g}}-\mathrm{T}_{\mathrm{pv}}\right)
\end{aligned}
$$

The Nusselt number $\left(\mathrm{Nu}_{\mathrm{a}}\right)$ used can be evaluated using Eq. 8 [41]

$$
\mathrm{Nu}_{\mathrm{a}}=1+1.44\left[1-\frac{1708}{\operatorname{Ra}_{\mathrm{a}} \cos \theta}\right] *\left[1-\frac{1708(\sin \theta)^{1.66}}{\operatorname{Ra}_{\mathrm{a}} \cos \theta}\right]+\left[\frac{\left(\mathrm{Ra} \delta_{\mathrm{a}} \cos \theta\right)^{0.33}}{5830}-1\right] *
$$

$\mathrm{Q}_{\text {cond, } \mathrm{g}}=\mathrm{A}_{\mathrm{g}} \mathrm{k}_{\mathrm{g}} \delta_{\mathrm{g}}\left(\frac{\partial^{2} \mathrm{~T}_{\mathrm{g}}(\mathrm{x}, \mathrm{y})}{\partial \mathrm{x}^{2}}+\frac{\partial^{2} \mathrm{~T}_{\mathrm{g}}(\mathrm{x}, \mathrm{y})}{\partial \mathrm{y}^{2}}\right)$

Photovoltaic module

Using thermal energy balance, we have 
$\mathrm{m}_{\mathrm{pv}} \mathrm{C}_{\mathrm{pv}} \frac{\mathrm{dT}_{\mathrm{pv}}}{\mathrm{dt}}=\mathrm{Q}_{\mathrm{in}, \mathrm{pv}}-\mathrm{Q}_{\mathrm{conv}, \mathrm{pv} \rightarrow \mathrm{g}}-\mathrm{Q}_{\mathrm{ray}, \mathrm{pv} \rightarrow \mathrm{g}}+\mathrm{Q}_{\mathrm{cond}, \mathrm{pv} \rightarrow \mathrm{pab}}-\mathrm{Q}_{\mathrm{elec}}+\mathrm{Q}_{\mathrm{cond}, \mathrm{pv}}$

271 The photovoltaic energy balance (Eq. 10) is determined by considering that the stocked energy by the

272 module $\left(\mathrm{m}_{\mathrm{pv}} \mathrm{C}_{\mathrm{pv}} \frac{\mathrm{dT}_{\mathrm{pv}}}{\mathrm{dt}}\right)$ is identical to the sum of the absorbed solar energy amount by module $\left(\mathrm{Q}_{\mathrm{in}, \mathrm{pv}}\right)$, heat 273 flux by conduction inside the photovoltaic layer $\left(Q_{\text {cond,pv }}\right)$, flux conduction transferred from module to 274 absorber sheet $\left(Q_{c o n d, p v \rightarrow p a b}\right)$ minus the sum of the radiation exchange flux $\left(Q_{\text {ray,pv } \rightarrow \mathrm{g}}\right)$ and convective $275\left(\mathrm{Q}_{\mathrm{conv}, \mathrm{pv} \rightarrow \mathrm{g}}\right)$ between the module and the glazing, and the electrical energy generated by the solar cells $276\left(Q_{\text {elec }}\right)$

277 The absorbed solar energy amount by module $\left(Q_{\text {in,pv }}\right)$ is described by Eq.11

$$
\mathrm{Q}_{\mathrm{in}, \mathrm{pv}}=\alpha_{\mathrm{pv}} \mathrm{G} \tau_{\mathrm{g}}
$$

Where $\alpha_{\mathrm{pv}}$ solar cell absorption coefficient.

Where $\mathrm{k}_{\mathrm{ad}}$ and $\delta_{\mathrm{ad}}$ are thermal conductivity and thickness adhesive layer, respectively.

290

The electrical energy generated by the solar cells $\left(Q_{\text {elec }}\right)$ is evaluated using the following empirical formula [42]:

$$
\mathrm{Q}_{\text {elec }}=\mathrm{G} \tau_{\mathrm{g}} \eta_{\mathrm{elec}} \mathrm{Pac} \eta_{\mathrm{o}}\left[1-\beta\left(\mathrm{T}_{\mathrm{pv}}-\mathrm{T}_{\mathrm{ref}}\right)\right]
$$

Where $\beta$ is the solar cell temperature coefficient $(0.0045), \eta_{0}$ is the reference efficiency for a reference temperature $\left(25^{\circ} \mathrm{C}\right)$, Pac is the packing factor and $\mathrm{T}_{\mathrm{pv}}$ is the operating photovoltaic module temperature.

The conduction flux transferred from module to absorber sheet $\left(Q_{\text {cond,pv } \rightarrow \text { pab }}\right)$ is described as follows:

$$
\mathrm{Q}_{\text {cond,pv } \rightarrow \mathrm{pab}}=\mathrm{R}_{\mathrm{pv}, \mathrm{pab}} \Delta \mathrm{T}
$$

Where the thermal conductance between the photovoltaic module and the absorber sheet is describes as:

$$
\mathrm{R}_{\mathrm{pv}, \mathrm{pab}}=\frac{\mathrm{k}_{\mathrm{ad}}}{\delta_{\mathrm{ad}}}
$$

The conduction flux inside PV module $\left(\mathrm{Q}_{\text {cond,pv }}\right)$ is defined as

$$
\mathrm{Q}_{\text {cond,pv }}=\mathrm{A}_{\mathrm{pv}} \mathrm{k}_{\mathrm{pv}} \delta_{\mathrm{pv}}\left(\frac{\partial^{2} \mathrm{~T}_{\mathrm{pv}}(\mathrm{x}, \mathrm{y})}{\partial \mathrm{x}^{2}}+\frac{\partial^{2} \mathrm{~T}_{\mathrm{pv}}(\mathrm{x}, \mathrm{y})}{\partial \mathrm{y}^{2}}\right)
$$


Using thermal energy balance for the absorber sheet, we have

$\mathrm{m}_{\mathrm{pab}} \mathrm{C}_{\mathrm{pab}} \frac{\mathrm{dT}_{\mathrm{pab}}}{\mathrm{dt}}=\mathrm{Q}_{\mathrm{cond}, \mathrm{pv} \rightarrow \mathrm{g}}-\mathrm{Q}_{\mathrm{cond}, \mathrm{pab} \rightarrow \mathrm{tu}}-\mathrm{Q}_{\mathrm{cond}, \mathrm{pab} \rightarrow \mathrm{is}}+\mathrm{Q}_{\mathrm{cond}, \mathrm{pab}}$

295

$$
\begin{aligned}
\rho_{\mathrm{t}} \delta_{\mathrm{t}} \mathrm{A}_{\mathrm{t}} \mathrm{dy} \mathrm{C}_{\mathrm{t}} \frac{\mathrm{dT} \mathrm{t}}{\mathrm{dt}}= & \mathrm{A}_{\text {pab, }} \mathrm{h}_{\text {cond,pab } \rightarrow \mathrm{t}}\left(\mathrm{T}_{\text {pab }}-\mathrm{T}_{\mathrm{t}}\right)+\mathrm{Peh}_{\text {conv }, \mathrm{t} \rightarrow \mathrm{f}} \mathrm{dy}\left(\mathrm{T}_{\mathrm{f}}-\mathrm{T}_{\mathrm{t}}\right) \\
& +\mathrm{A}_{\mathrm{i}, \mathrm{t}} \mathrm{h}_{\text {cond, } \mathrm{t} \rightarrow \mathrm{i}}\left(\mathrm{T}_{\mathrm{i}}-\mathrm{T}_{\mathrm{t}}\right)+\mathrm{k}_{\mathrm{t}} \delta_{\mathrm{t}}\left(\frac{\partial^{2} \mathrm{~T}_{\mathrm{t}}}{\partial^{2} \mathrm{y}}\right)
\end{aligned}
$$

The insulation energy balance (Eq. 21) is determined by considering that the stocked energy by the tube $\left(\rho_{t} \delta_{t} A_{t} d y C_{t} \frac{d T_{t}}{d t}\right)$ is identical to the sum of heat flux by conduction inside the tube $k_{t} \delta_{t}\left(\frac{\partial^{2} T_{t}}{\partial^{2} y}\right)$, and the flux conduction transferred from the absorber sheet to the tube $A_{p a b, t} h_{c o n d, p a b \rightarrow t}\left(T_{p a b}-T_{t}\right)$ minus the heat

The absorber sheet energy balance (Eq. 1) is determined by considering that the stocked energy by the module $\left(\mathrm{m}_{\mathrm{pab}} \mathrm{C}_{\mathrm{pab}} \frac{\mathrm{d} \mathrm{T}_{\mathrm{pab}}}{\mathrm{dt}}\right)$ is identical to the sum of heat flux by conduction inside the absorber sheet $\left(Q_{\text {cond,pab }}\right)$, and the flux conduction transferred from module to the absorber sheet $\left(Q_{\text {cond,pv } \rightarrow \mathrm{pab}}\right)$ minus the flux conduction transferred from absorber sheet to tube $\left(Q_{\text {cond,pab } \rightarrow \text { tu }}\right)$ and from absorber to insulation $Q_{\text {cond,pab } \rightarrow \text { is }}$

The flux by conduction inside the absorber sheet $\left(Q_{\text {cond,pab }}\right)$ is defined as Eq.17:

$\mathrm{Q}_{\text {cond,pab }}=\mathrm{A}_{\mathrm{pab}} \mathrm{k}_{\mathrm{pab}} \delta_{\mathrm{pab}}\left(\frac{\partial^{2} \mathrm{~T}_{\mathrm{pab}}(\mathrm{x}, \mathrm{y})}{\partial \mathrm{x}^{2}}+\frac{\partial^{2} \mathrm{~T}_{\mathrm{pab}}(\mathrm{x}, \mathrm{y})}{\partial \mathrm{y}^{2}}\right)$

The conduction flux transferred from the absorber sheet to the tube $\left(Q_{\mathrm{cond}, \mathrm{pv} \rightarrow \mathrm{pab}}\right)$ is described as:

$\mathrm{Q}_{\text {convd,pab } \rightarrow \mathrm{tu}}=\mathrm{A}_{\mathrm{pab}, \mathrm{tu}} \mathrm{h}_{\text {cond,pab } \rightarrow \mathrm{tu}}\left(\mathrm{T}_{\mathrm{tu}}-\mathrm{T}_{\mathrm{pab}}\right)$

Where $A_{p a b, t u}$ is the contact area between the absorber sheet and the tube [3]:

$$
\mathrm{A}_{\mathrm{pab}, \mathrm{tu}}=\frac{\pi \mathrm{Rdy}}{2}
$$
exchange by convection between the tube and the fluid cooling $P_{\text {conv, } t \rightarrow f} d y\left(T_{f}-T_{t}\right)$ and the flux conduction transferred from the tube to the insulation $Q_{\text {cond,tu } \rightarrow \text { is }}$

Bejan [43] suggested a correlation for the Nusselt number, it is utilized in our work 
$\operatorname{Re}>2300 \Rightarrow \mathrm{Nu}_{\mathrm{t}}=0.023 \operatorname{Re}^{0.8} \operatorname{Pr}^{0.4}$

The energy balance of the fluid leads to

$\rho_{\mathrm{f}} \mathrm{A}_{\mathrm{f}} \mathrm{dyC}_{\mathrm{f}} \frac{\mathrm{dT} \mathrm{T}_{\mathrm{f}}}{\mathrm{dt}}=\operatorname{Peh}_{\mathrm{conv}, \mathrm{t} \rightarrow \mathrm{f}} \mathrm{dy}\left(\mathrm{T}_{\mathrm{t}}-\mathrm{T}_{\mathrm{f}}\right)-\dot{\mathrm{m}}_{\mathrm{f}} \Delta \mathrm{T}_{\mathrm{f}}$

The fluid energy balance (Eq. 23) is estimated by considering that the stored energy by the fluid $\left(\rho_{\mathrm{f}} \mathrm{A}_{\mathrm{f}} \mathrm{dyC}_{\mathrm{f}} \frac{\mathrm{dT}_{\mathrm{f}}}{\mathrm{dt}}\right)$ is identical to the heat flux by convection between the tube and the fluid $\operatorname{Peh}_{\text {conv, } t \rightarrow f} d y\left(T_{f}-T_{t}\right)$ minus the heat extracted by the water flow rate $\left(\dot{m}_{\mathrm{f}} \Delta T_{f}\right)$.

The insulation energy balance (Eq. 24) is determined by considering that the stocked energy by the insulation layer $\left(\rho_{\text {is }} \delta_{\text {is }} \mathrm{C}_{\mathrm{is}} \frac{\mathrm{dT} \text { is }}{\mathrm{dt}}\right)$ is identical to the sum of heat flux by conduction inside the insulation sheet $\left(Q_{\text {cond,in }}\right)$, and the flux conduction transferred from absorber sheet to insulation $\left(Q_{c o n d, p a b \rightarrow i s}\right)$ and from the tube to the insulation $\left(Q_{\text {cond,tu } \rightarrow \text { is }}\right)$ minus the heat exchange by convection between the insulation and the surroundings $\left(Q_{\text {conv,is } \rightarrow \text { amb }}\right)$

$\rho_{\text {is }} \delta_{\text {is }} C_{\text {is }} \frac{\mathrm{dT}_{\text {is }}}{\mathrm{dt}}=-\mathrm{Q}_{\text {conv,is } \rightarrow \mathrm{amb}}+\mathrm{Q}_{\text {cond,is }}+\mathrm{Q}_{\text {cond,tu } \rightarrow \text { is }}+Q_{\text {cond,pab } \rightarrow \text { is }+} Q_{\text {cond,is }}$

$\left(Q_{\text {conv,is } \rightarrow \text { amb }}\right)$ is the wind convection exchange from the insulation to ambient and it is calculated using the MacAdams empirical formula [3]:

$\left(\mathrm{Q}_{\text {conv,is } \rightarrow \mathrm{amb}}\right)=\mathrm{A}\left(5.7+3.8 \mathrm{~V}_{\mathrm{wi}}\right)\left(\mathrm{T}_{\mathrm{amb}}-\mathrm{T}_{\mathrm{is}}\right)$

The flux by conduction inside the insulation $\left(\mathrm{Q}_{\text {cond,is }}\right)$ is defined as:

$\mathrm{Q}_{\text {cond,is }}=\mathrm{A}_{\mathrm{is}} \mathrm{k}_{\mathrm{is}} \delta_{\text {is }}\left(\frac{\partial^{2} \mathrm{~T}_{\mathrm{is}}(\mathrm{x}, \mathrm{y})}{\partial \mathrm{x}^{2}}+\frac{\partial^{2} \mathrm{~T}_{\mathrm{is}}(\mathrm{x}, \mathrm{y})}{\partial \mathrm{y}^{2}}\right)$

\subsection{Proposed PVT Collector with Channel}

The advanced PVT channelled collector (Fig. 2) was arranged to perform at smaller solar cell temperature and larger water temperature than the first PVT sheet and tube configuration. The main distinguishing 
component of the second collector. An anti-reflective coating (ARC) is applied to transparent covers and encapsulation surfaces and can be beneficial for both the thermal and electrical efficiencies. A lowemissivity coating is applied and can improve the thermal efficiency for collectors operating at high temperatures, but their inherent transmission losses reduce the electrical efficiency. A channel heat exchanger is used to decrease the thermal losses between the solar cells and the cooling fluid.

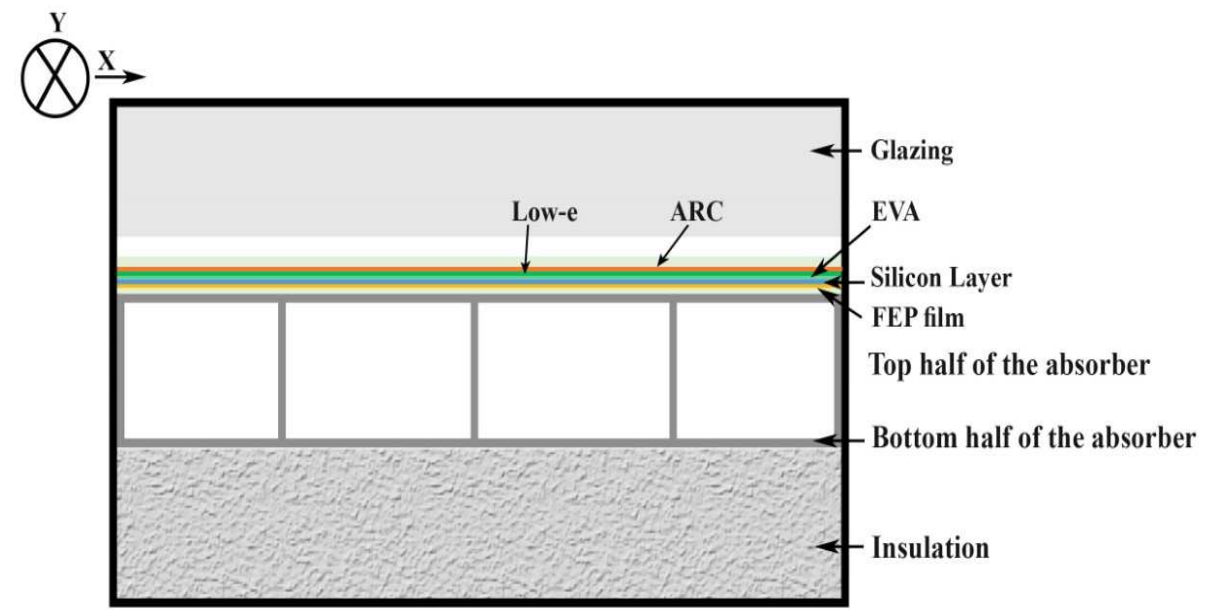

Figure 2: The advanced PVT channelled collector considered in the present study

For the upper half of Absorber

The thermal energy balance of the upper half of the absorber leads to

$\mathrm{m}_{\mathrm{pabu}} \mathrm{C}_{\mathrm{pabu}} \frac{\mathrm{dT}_{\mathrm{pabu}}}{\mathrm{dt}}=\mathrm{h}_{\mathrm{cond}, \mathrm{pv} \rightarrow \mathrm{pabu}}\left(\mathrm{T}_{\mathrm{pv}}-\mathrm{T}_{\mathrm{pabu}}\right)+\frac{\mathrm{A}_{\mathrm{pabu}, \mathrm{f}}}{\mathrm{A}_{\mathrm{pbu}}} \mathrm{h}_{\text {conv,pabu } \rightarrow \mathrm{f}}\left(\mathrm{T}_{\mathrm{f}}-\mathrm{T}_{\mathrm{pabu}}\right)$

$+\frac{A_{\text {pabu,pabh }}}{A_{\text {pbu }}} h_{\text {cond,pabu } \rightarrow \text { pabh }}\left(T_{\text {pabh }}-T_{\text {pabu }}\right)+k_{\text {pabu }} \delta_{\text {pabu }}\left(\frac{\partial^{2} \mathrm{~T}_{\text {pabu }}(\mathrm{x}, \mathrm{y})}{\partial \mathrm{x}^{2}}+\frac{\partial^{2} \mathrm{~T}_{\mathrm{pabu}}(\mathrm{x}, \mathrm{y})}{\partial \mathrm{y}^{2}}\right)$

The thermal energy balance of the lower half of the absorber leads to

$$
\begin{aligned}
& \mathrm{m}_{\text {pabh }} \mathrm{C}_{\text {pabh }} \frac{\mathrm{dT}_{\text {pabh }}}{\mathrm{dt}}=\mathrm{h}_{\text {cond,pabh } \rightarrow \mathrm{is}}\left(\mathrm{T}_{\mathrm{is}}-\mathrm{T}_{\mathrm{pabh}}\right)+\frac{\mathrm{A}_{\mathrm{pabh}, \mathrm{f}}}{\mathrm{A}_{\mathrm{pbh}}} \mathrm{h}_{\text {conv,pabh } \rightarrow \mathrm{f}}\left(\mathrm{T}_{\mathrm{f}}-\mathrm{T}_{\mathrm{pabh}}\right) \\
& +\frac{\mathrm{A}_{\text {pabu,pabh }}}{\mathrm{A}_{\mathrm{pbh}}} \mathrm{h}_{\text {cond,pabu } \rightarrow \text { pabh }}\left(\mathrm{T}_{\text {pabu }}-\mathrm{T}_{\text {pabh }}\right)+\mathrm{k}_{\mathrm{pabh}} \delta_{\text {pabh }}\left(\frac{\partial^{2} \mathrm{~T}_{\mathrm{pabh}}(\mathrm{x}, \mathrm{y})}{\partial \mathrm{x}^{2}}+\frac{\partial^{2} \mathrm{~T}_{\text {pabh }}(\mathrm{x}, \mathrm{y})}{\partial \mathrm{y}^{2}}\right)
\end{aligned}
$$


The thermal energy balance of the heat carrier fluid leads to

354

$$
+A_{\text {pabh, }} \mathrm{h}_{\text {conv,pabh } \rightarrow f}\left(\mathrm{~T}_{\text {pabu }}-\mathrm{T}_{\mathrm{f}}\right)
$$

$>$ For the insulation layer

The thermal energy balance of the insulation leads to

$\mathrm{m}_{\text {is }} \mathrm{C}_{\text {is }} \frac{\mathrm{dT}_{\mathrm{is}}}{\mathrm{dt}}=\mathrm{h}_{\mathrm{wind}}\left(\mathrm{T}_{\mathrm{amb}}-\mathrm{T}_{\mathrm{is}}\right)+\mathrm{h}_{\text {cond,pabh } \rightarrow \text { is }}\left(\mathrm{T}_{\mathrm{is}}-\mathrm{T}_{\mathrm{pabh}}\right)+\mathrm{k}_{\mathrm{is}} \delta_{\text {is }}\left(\frac{\partial^{2} \mathrm{~T}_{\mathrm{is}}(\mathrm{x}, \mathrm{y})}{\partial \mathrm{x}^{2}}+\frac{\partial^{2} \mathrm{~T}_{\text {is }}(\mathrm{x}, \mathrm{y})}{\partial \mathrm{y}^{2}}\right)$

\section{Numerical Solution and validation}

\subsection{Numerical Solution}

The system of the differential equations described above is nonlinear. Therefore, rather than attempting to obtain an analytical treatment, it is numerically discretized and solved using the finite volume method (FVM). The general approach of the FVM involves the definition of the control volumes to contain the nodes associated with the state variables of the model. The governing heat balance equations for the two different collectors presented in the above sections were solved by the classical two-dimensional FVM and an implicit method. The entire computational domain is discretised using a uniform structured $130 * 100$ mesh. This grid value is based on the mesh independency analyses for a $2 \mathrm{~m} \times 1 \mathrm{~m}$ surface PVT conducted with an uniform mesh of constant control volume dimensions $\Delta \mathrm{x}$ and $\Delta \mathrm{y}$ for internal cells, and half and quarter volumes for edges and corners of each body (Fig.3). The mathematical established model is implemented in a Fortran platform in accordance to the simulation algorithm procedural summarized in Fig. 4. In order to numerically the discretized equations system, an iterative Gaussian elimination method isused. The simulation starts by initiating arbitrary temperatures of glass, PV, absorber, tube and insulation equal to the ambient temperature, as well as the temperature of working fluid is equal to the inlet water temperature and then solved iteratively until the convergence criteria is obtained. This criteria is defined by a threshold in the relative discrepancy $\left(10^{-9}\right)$. The calculation is repeated for all nodes before proceeding to the next time step $(\Delta \mathrm{t}=1 \mathrm{~s})$, initiated using the latest solution. 


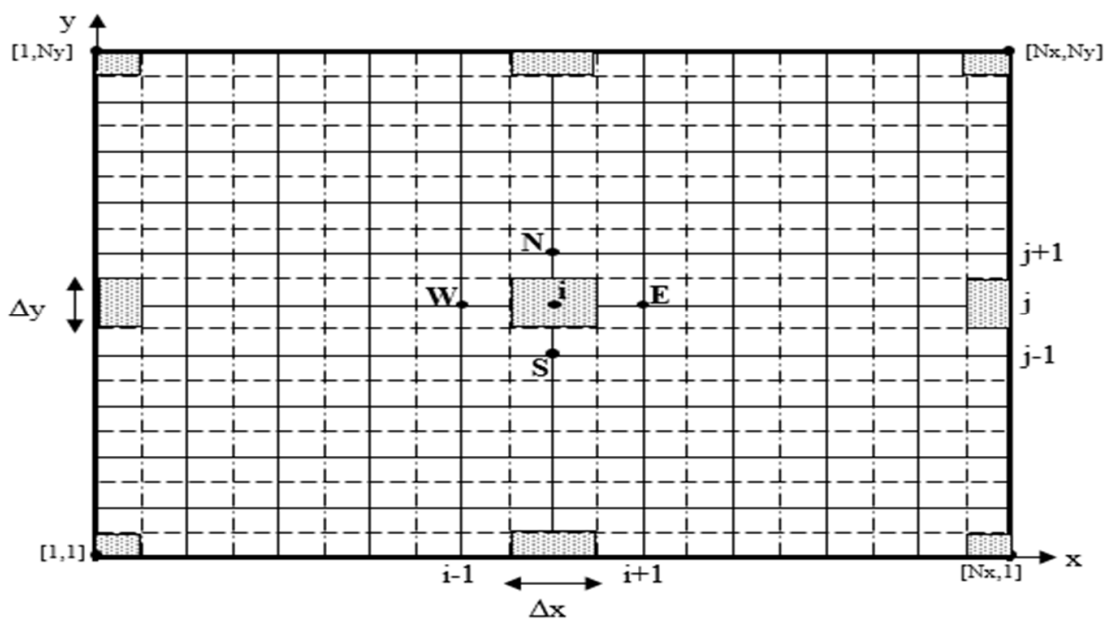

Figure 3: Mesh describing the spatial discretisation of the system

378 The physical size value $(T)$ in the node $[i, j]$, at time $t+\Delta t$ is considered to be $T_{i, j}(t+\Delta t)$.

379 For the temporal discretization, an unsteady state implicit scheme was adopted as follows:

$\int_{\mathrm{t}}^{\mathrm{t}+\Delta \mathrm{t}} \mathrm{T}(\mathrm{t}) \mathrm{dt}=(\mathrm{T}(\mathrm{t}+\Delta \mathrm{t})-\mathrm{T}(\mathrm{t})) \Delta \mathrm{t}=\left(\mathrm{T}-\mathrm{T}_{0}\right) \Delta \mathrm{t}$

381 where the accumulation and the source terms are assumed to be constant inside each control volume. The

382 first derivatives in space on the faces of the control domain are evaluated assuming that the variations

383 between two neighbouring nodes are linear (Eq. 31 to 34 ).

$\left(\frac{\partial T}{\partial x}\right)_{i+\frac{1}{2}, j=\frac{T[i+1, j]-T[i, j]}{\Delta x}}$

$\left(\frac{\partial T}{\partial x}\right)_{i-\frac{1}{2}, j}=\frac{T[i, j]-T[i-1, j]}{\Delta x}$

$\left(\frac{\partial T}{\partial x}\right)_{i, j+\frac{1}{2}=\frac{T[i, j+1]-T[i, j]}{\Delta y}}$

$\left(\frac{\partial T}{\partial x}\right)_{i, j-\frac{1}{2}=\frac{T[i, j]-T[i, j-1]}{\Delta y}}$

Using these hypotheses, the discretized equations can be written as follows:

$a_{0} T[i, j]=a_{s} T[i, j-1]+a_{n} T[i, j+1]+a_{w} T[i-1, j]+a_{e} T[i+1, j]+b$

$a_{0}, a_{s}, a_{n}, a_{w}, a_{e}, b$ are coefficients that are depending on the selected solutions profiles, physical properties and calculation steps. 
Using these hypotheses, the discretized equations can be written as follows:

$394 \mathrm{a}_{0}, \mathrm{a}_{\mathrm{s}}, \mathrm{a}_{\mathrm{n}}, \mathrm{a}_{\mathrm{w}}, \mathrm{a}_{\mathrm{e}}, \mathrm{b}$ are the coefficients that are depending on the selected solutions profiles, physical 395 properties and calculation steps.

396 As an example, if we consider the case for the inside face of the photovoltaic module, by grouping the 397 equations (Eq.10-15 and Eq. 43-47), the resultant becomes (Eq. 37 to 42):

398

$a_{0}=\left[\left(\rho_{p v} C_{p v} \delta_{p v} \Delta x \Delta y\right)+h_{r a y, p v->g} \Delta t \Delta x \Delta y+h_{c o n v, p v->g} \Delta t \Delta x \Delta y+h_{c o n d, p a b->p v} \Delta t \Delta x \Delta y+k_{p v} \delta_{p v} \frac{\Delta t \Delta y}{\Delta x}\right.$ $\left.+k_{p v} \delta_{p v} \frac{\Delta t \Delta y}{\Delta x}+k_{p v} \delta_{p v} \frac{\Delta t \Delta x}{\Delta y}+k_{p v} \delta_{p v} \frac{\Delta t \Delta x}{\Delta y}\right]$

399

$a_{w}=k_{p v} \delta_{p v} \frac{\Delta t \Delta y}{\Delta x}$

400

$a_{e}=k_{p v} \delta_{p v} \frac{\Delta t \Delta y}{\Delta x}$

401

$a_{s}=k_{p v} \delta_{p v} \frac{\Delta t \Delta x}{\Delta y}$

402

$a_{n}=k_{p v} \delta_{p v} \frac{\Delta t \Delta x}{\Delta y}$

403

$b=\left(\rho_{p v} C_{p v} \delta_{p v} \Delta x \Delta y T_{p v(i, j)}^{t}\right)+h_{r a y, p v->g} T_{g(i, j)}^{t+d t} \Delta t \Delta x \Delta y+h_{c o n v, p v->g} T_{g(i, j)}^{t+d t} \Delta t \Delta x \Delta y$

$+h_{\text {cond }, p a b->p v} T_{p a b(i, j)}^{t+d t} \Delta t \Delta x \Delta y$

404

405 


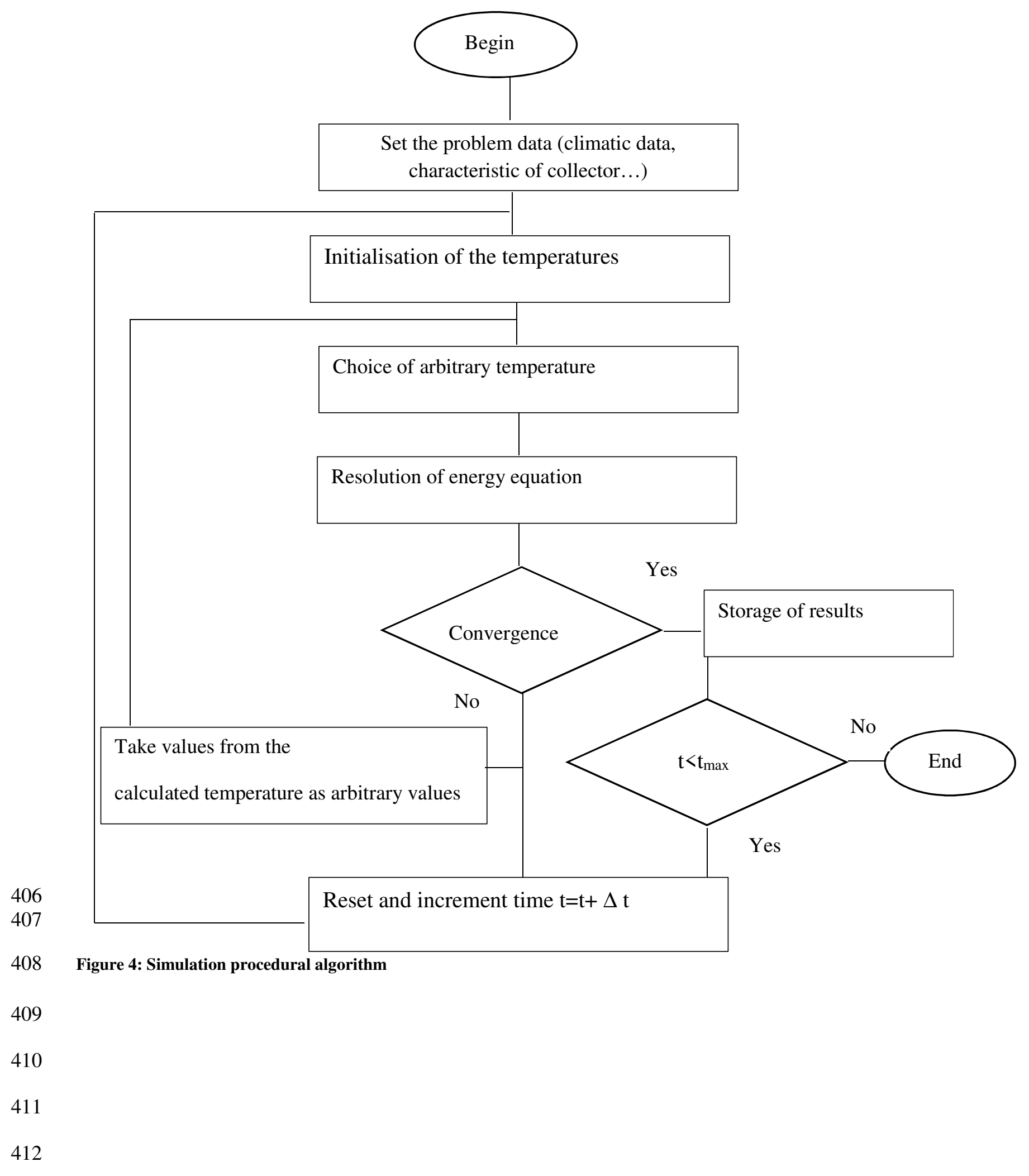


414 The collector performance is characterised by the thermal and electrical efficiencies as a function of the reduced temperature. The reduced temperature corresponds to the temperature difference between the fluid and the ambient divided by the solar radiation. The thermal efficiency is defined by

$\eta_{\mathrm{th}}=\dot{\mathrm{m}}_{\mathrm{w}} \mathrm{C}_{\mathrm{p}} \frac{(\mathrm{Tm}-\mathrm{Tamb})}{\mathrm{GA}}$

where $\mathrm{T}_{\mathrm{m}}$ is the average of inlet and outlet temperatures, $\mathrm{T}_{\text {out }}-T_{\text {in }}$, and $\dot{\mathrm{m}}_{\mathrm{w}}$ is the mass flow rate.

According to the EN 12975 standard, the thermal efficiency is given by the following equation and it is related to the thermal conversion factor for the no loss $\left(\eta_{0}\right)$, linear heat loss coefficient (C1) and Temperature dependence of heat losses $(\mathrm{C} 2)$

$\eta_{\text {th }}=\eta_{0}-C_{1}\left[\frac{(\text { Tin }- \text { Tamb })}{G}\right]-C_{2}\left[\frac{(\text { Tin-Tamb })^{2}}{G}\right]$

$\eta_{\text {elec }}=\eta_{\text {elec, }, 0}-C_{3}\left[\frac{(\text { Tin-Tamb })}{G}\right]$

The validation of the numerical model associated with the PVT sheet and tube collector is achieved by the comparison with the fittings results obtained experimentally on the EN 12975 standard steady state efficiencies by Bhattarai [44] (see Fig.5). Table 1 summarizes the parameters of the collector. We kept the same physical properties of the collector components, the surface of the PVT collector and the arrangement of the tubes used by Bhattarai [44] in our numerical code. A good concurrence was obtained for this first model.

To assess the extent of agreement our numerical model, the mean root square deviation (RMS) is performed. It is defined as follows:

$R M S=\frac{\sqrt{\frac{\sum\left(100 *\left(\mathrm{x}_{\text {exp }, \mathrm{i}}-\mathrm{x}_{\text {num }, \mathrm{i}}\right)\right.}{\left(\mathrm{x}_{\mathrm{exp}, \mathrm{i}}\right)^{2}}}}{\mathrm{n}_{\exp }}$

where $X_{\text {expi }}$ and $X_{\text {numi }}$ denote the experimental and numerical results, respectively.

The RMS of electrical and thermal efficiencies are $2.31 \%, 0.57 \%$, respectively. Therefore, we have obtained a satisfactory conformance. The numerical model reproduces the dynamics observed in the experiment, and the response of the collector to varying environmental conditions. The curves in Fig. 5a 
describe the correlation of thermal efficiency to reduced temperature, obtained by fitting experimental data (eq.47) from [44], and the correlation resulting from the simulation (eq.48).

$\eta_{\text {th, exp linear fitting }}=0.5887-7.0524\left[\frac{(\mathrm{Tm}-\mathrm{Tamb})}{\mathrm{G}}\right]-0.269\left[\frac{(\mathrm{Tm}-\mathrm{Tamb})^{2}}{\mathrm{G}}\right]$

$\eta_{\text {th, modeling, present work }}=0.58-6.8\left[\frac{(\mathrm{Tm}-\mathrm{Tamb})}{\mathrm{G}}\right]-0.025\left[\frac{(\mathrm{Tm}-\mathrm{Tamb})^{2}}{\mathrm{G}}\right]$

The curves in Fig. 5b describe the correlation of electrical efficiency to reduced temperature, obtained by fitting experimental data (eq.49) from [44], and the correlation resulting from the simulation (eq.50).

$\eta_{\text {elec, modeling,present work }}=0.137-0.5\left[\frac{(\text { Tin-Tamb })}{G}\right]$

$\eta_{\text {elec, exp linear fitting }}=0.1369-0.477\left[\frac{(\mathrm{Tm}-\mathrm{Tamb})}{\mathrm{G}}\right]$

A good agreement is observed, especially for thermal efficiency versus a values of reduced temperature inferior to $0.075 \mathrm{Km}^{2} / \mathrm{W}$, and for electrical efficiency versus a values of reduced temperature inferior to $0.06 \mathrm{Km}^{2} / \mathrm{W}$. A gradual divergence is evident towards higher ambient temperature and solar radiation flux. Considering that uncertainties in material properties and parameters were small, the discrepancy was attributed to an underestimation of losses by convection to ambient air and long wave radiation by the model compared to the experiment. The deviation amounts to an overestimation of thermal efficiency by $0.05 \%$ for a reduced temperature of $0.08 \mathrm{Km}^{2} / \mathrm{W}$, which can be considered the difference in performance between an ideal collector and a real system. For the parametric analysis presented in the following sections, this systematic error is assumed invariant for all the configurations.

A second validation was undertaken using the experimental results obtained by Sarradarbadi et al [45], who evaluated the efficiencies of an uncovered PVT-water collector under Mashad (Iran) climatic conditions. The numerical simulation was conducted under the experimental conditions given in [45]. Taking into account the difference in experimental set up, some changes were applied to the model. In particular, the glass layer was removed, and the balance energy equation was substituted as follows (Eq. 51): 


$$
\begin{gathered}
\mathrm{m}_{\mathrm{pv}} \mathrm{C}_{\mathrm{pv}} \frac{\mathrm{dT}_{\mathrm{pv}}}{\mathrm{dt}}=\mathrm{h}_{\mathrm{cond}, \mathrm{pv} \rightarrow \mathrm{pabu}}\left(\mathrm{T}_{\mathrm{pab}}-\mathrm{T}_{\mathrm{pv}}\right)+\alpha_{\mathrm{pv}} \mathrm{G}+\left(5.7+3.8 \mathrm{~V}_{\mathrm{wi}}\right)\left(\mathrm{T}_{\mathrm{amb}}-\mathrm{T}_{\mathrm{pv}}\right)-\mathrm{Q}_{\mathrm{elec}} \\
\varepsilon_{\mathrm{pv}} \sigma\left(\mathrm{T}_{\mathrm{pv}}^{2}+\mathrm{T}_{\mathrm{sky}}^{2}\right)\left(\mathrm{T}_{\mathrm{pv}}+\mathrm{T}_{\mathrm{sky}}\right)\left(\mathrm{T}_{\mathrm{pv}}-\mathrm{T}_{\mathrm{sky}}\right)+\mathrm{k}_{\mathrm{pv}} \delta_{\mathrm{pv}}\left(\frac{\partial^{2} \mathrm{~T}_{\mathrm{pv}}(\mathrm{x}, \mathrm{y})}{\partial \mathrm{x}^{2}}+\frac{\partial^{2} \mathrm{~T}_{\mathrm{pv}}(\mathrm{x}, \mathrm{y})}{\partial \mathrm{y}^{2}}\right)
\end{gathered}
$$

The predicted results provided by our code and experimental data of outlet water temperature are plotted in Fig. 5-c. It is noted that the simulation results agree well with the experimental data carried out by Sarradarbadi et al. [45]. The obtained RMS of outlet water temperature is $1.5 \%$. Therefore, we have the behaviour of PV T collector with low relative errors.

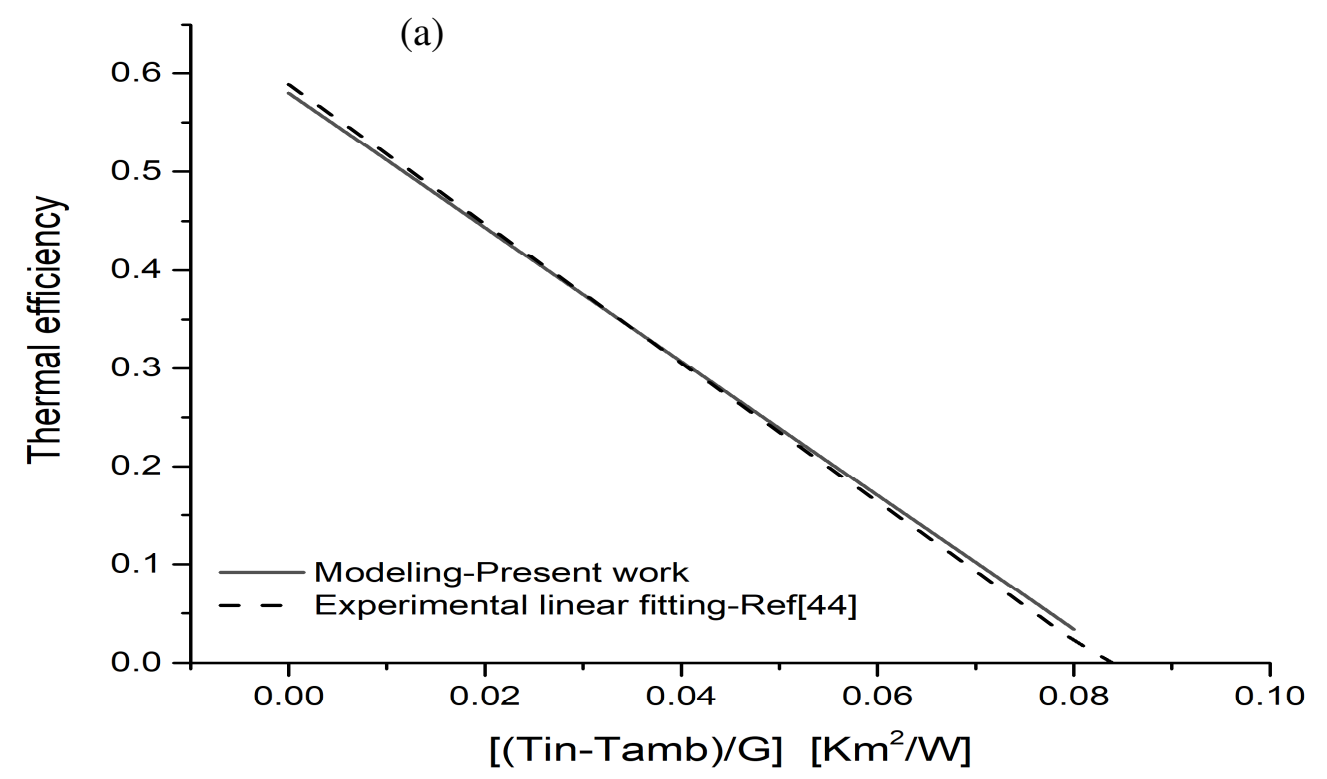

Figure 5-a: Comparison of predicted thermal efficiency with the experimental fit curve presented in [44]. 
(b)

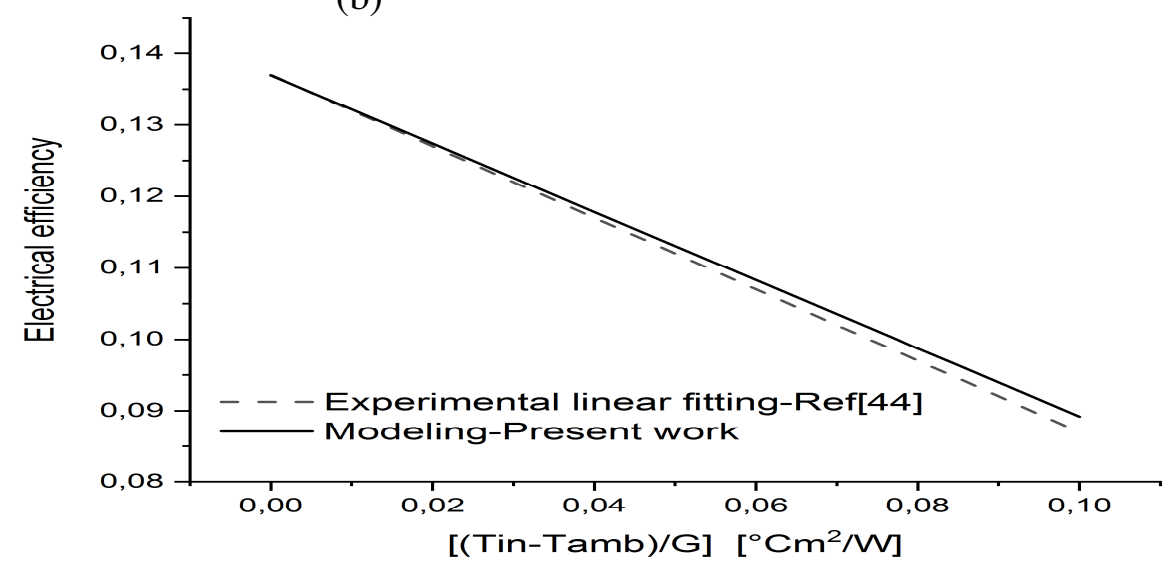

473

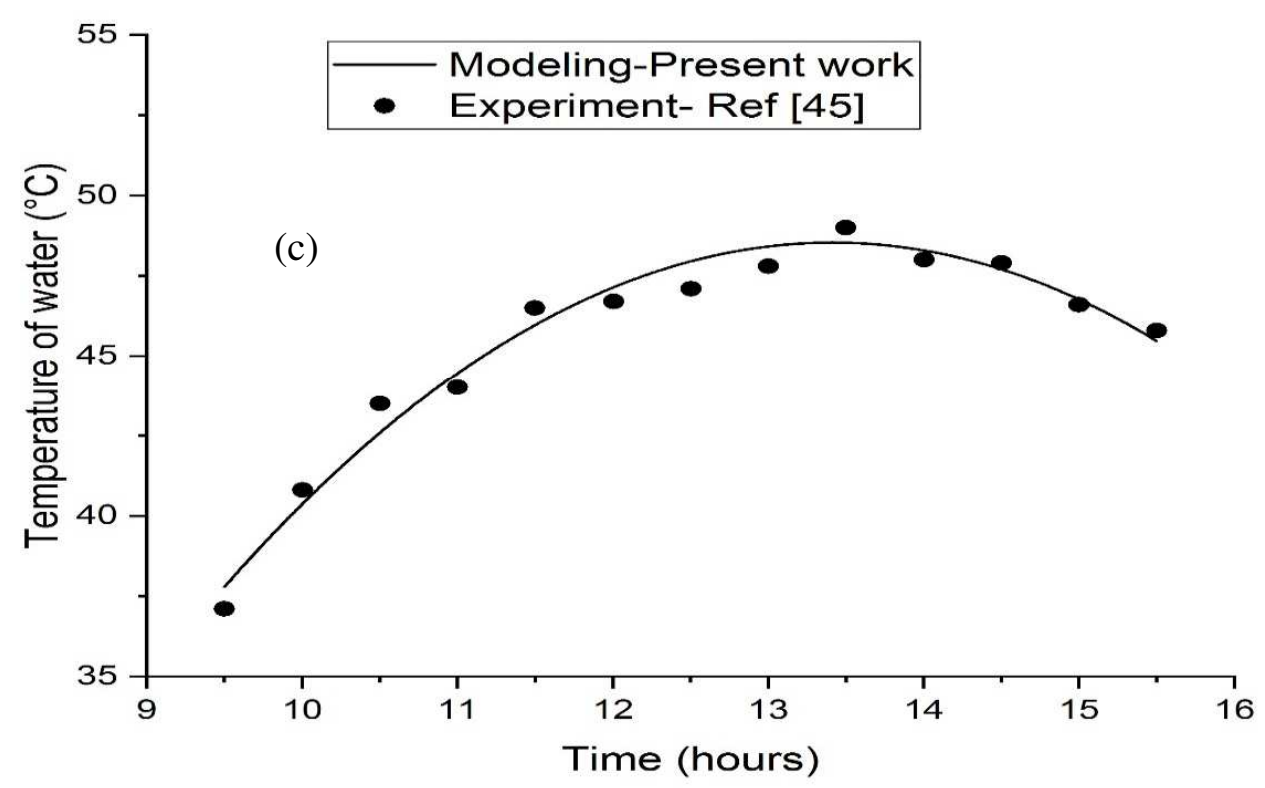

475

476 Figure 5-c: Comparison of the outlet water temperature versus the experimental results performed by Sarradarbadi et al.

[45]. 


\begin{tabular}{|c|c|c|}
\hline Components & PVT-sheet and tube & Parameters \\
\hline \multirow[t]{4}{*}{ Glazing } & $0.004 \mathrm{~m}$ & Thickness, $\delta_{g} 478$ \\
\hline & $670(J / \mathrm{kgK})$ & Specific heat, $\mathrm{Cg}_{779}$ \\
\hline & $2200\left(\mathrm{~kg} / \mathrm{m}^{3}\right)$ & Density, $\rho_{g} 480$ \\
\hline & $0.9(W / \mathrm{mK})$ & $\begin{array}{c}\text { Thermal conductivity, } \\
k_{g} \quad 481\end{array}$ \\
\hline \multirow[t]{4}{*}{ PV module } & $900(J / \mathrm{kgK})$ & Specific heat, $C_{\mathrm{p} 482}$ \\
\hline & $140(W / \mathrm{mK})$ & $\begin{array}{c}\text { Thermal } \\
\text { conductivity }, k_{\mathrm{pv}}^{483}\end{array}$ \\
\hline & 1 & Packing factor, $\mathrm{P}_{484}$ \\
\hline & $0.405 \mathrm{~K}-1$ & $\begin{array}{r}\text { Solar cell temperature } \\
\text { coefficient, } \beta 485 \\
\end{array}$ \\
\hline \multirow{2}{*}{ Absorber Plate } & $2702\left(\mathrm{~kg} / \mathrm{m}^{3}\right)$ & Density,$\rho_{\text {pab }} 486$ \\
\hline & $310(W / \mathrm{mK})$ & $\begin{array}{r}\text { Thermal conductivity } \\
k_{\mathrm{pab}} \quad 487\end{array}$ \\
\hline \multirow[t]{6}{*}{ Tube/channels } & $2702\left(\mathrm{~kg} / \mathrm{m}^{3}\right)$ & Density 488 \\
\hline & $310(W / \mathrm{mK})$ & $\begin{array}{r}\text { Thermal conductivity } \\
489\end{array}$ \\
\hline & 10 & Tube/channels number \\
\hline & $0.008 \mathrm{~m}$ & $\begin{array}{l}\text { Diameter of tube } \\
\text { length of channe }\end{array}$ \\
\hline & $0.004 \mathrm{~m}$ & $\begin{array}{c}\text { Radius of tube / width of } \\
\text { channel }\end{array}$ \\
\hline & $0.0012 \mathrm{~m}$ & Thickness \\
\hline \multirow[t]{3}{*}{ Insulation } & $0.05 \mathrm{~m}$ & Thickness,$\delta_{i}$ \\
\hline & $20\left(\mathrm{~kg} / \mathrm{m}^{3}\right)$ & Density, $\rho_{i} 494$ \\
\hline & $0.030(\mathrm{~W} / \mathrm{mK})$ & Thermal conductivit ${ }^{\prime} \phi_{\mathrm{v}}$ \\
\hline
\end{tabular}

Table 1: Parameter sets for the photovoltaic thermal (PVT) sheet and tube collector

\section{Results and Discussion}

In this section, the effect of the modification (optical coating, thermal resistance thermal between the photovoltaic and absorber plate, choice of the exchange area between the absorber exchanger and the cooling fluid) utilized to transform the basic PVT sheet and tube design to a most advantageous PVT configuration is examined and discussed. Moreover, a comparison between the advanced PVT collector and the basic ones is performed in terms of the temperature distribution.

According to the ISO 9806 standard, the thermal efficiency is given by the following equation and it is characterized by three fit-parameters namely $: \eta_{0}$ is the thermal conversion factor when the reduced temperature is equal to zero. $\mathrm{C}_{1}$ and $\mathrm{C}_{2}$ are linear and quadratic heat loss coefficients. 
Where $\mathrm{T}_{\mathrm{m}}$ is the average of inlet and outlet temperatures, $\mathrm{T}_{\text {out }}-T_{\text {in }}$, and $\dot{\mathrm{m}}_{\mathrm{w}}$ is the mass flow rate.

510 Performing linear regression of electrical efficiency $\eta_{\text {elec }}$ to reduced temperature $\left(\left[\frac{(\mathrm{Tm}-\mathrm{Tamb})}{\mathrm{G}}\right]\right)$ with the, 511 the thermal efficiency is given by the following equation:

$512 \quad \eta_{\text {elec }}=\eta_{\text {elec, } 0}-C_{3}\left[\frac{(\mathrm{Tm}-\mathrm{Tamb})}{\mathrm{G}}\right]$

513 Where

$514 \eta_{\text {elec, } 0}$ is Electrical conversion factor for the no loss, $C_{3}$ is the Linear temperature dependence factor

\subsection{Parametric study}

\subsection{The Impact of Optical Coatings Applied to the PVT Collector}

- Low-emissivity coatings

519 As shown in Fig.6, an increase of emissivity leads to an increase of the radiation heats loss and thus a 520 decrease of the thermal efficiency). The addition of a low-emissivity coating can overcome this drawback, however this also results in an increase in the reflectance, hence lower absorptance, and leads to a rise in collector temperature. The consequence is a fall in electrical efficiency. It is therefore interesting to choose an optimal value with regards to the electrical and thermal efficiencies. As shown in Fig.7, an emissivity of 0.45 offered the best compromise for the PVT configuration under investigation. 


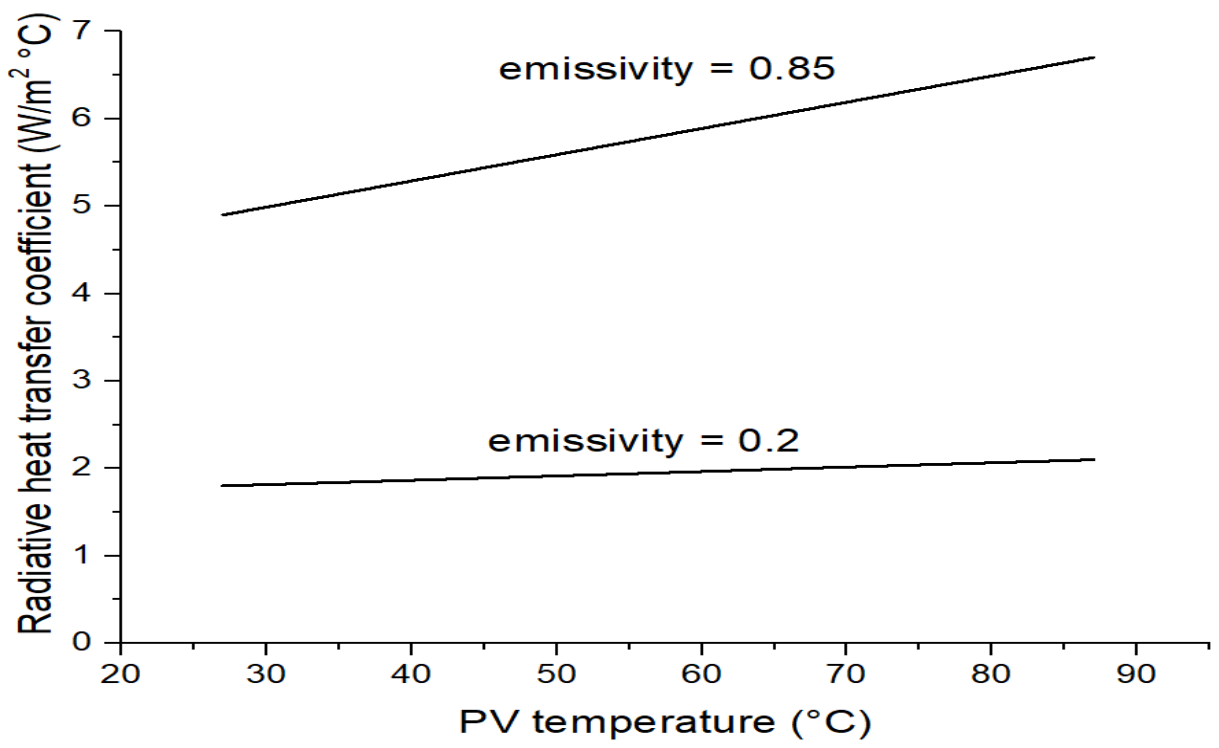

526 Figure 6: Radiative heat loss coefficient as function of photovoltaic module temperature for a range in longwave emissivity.

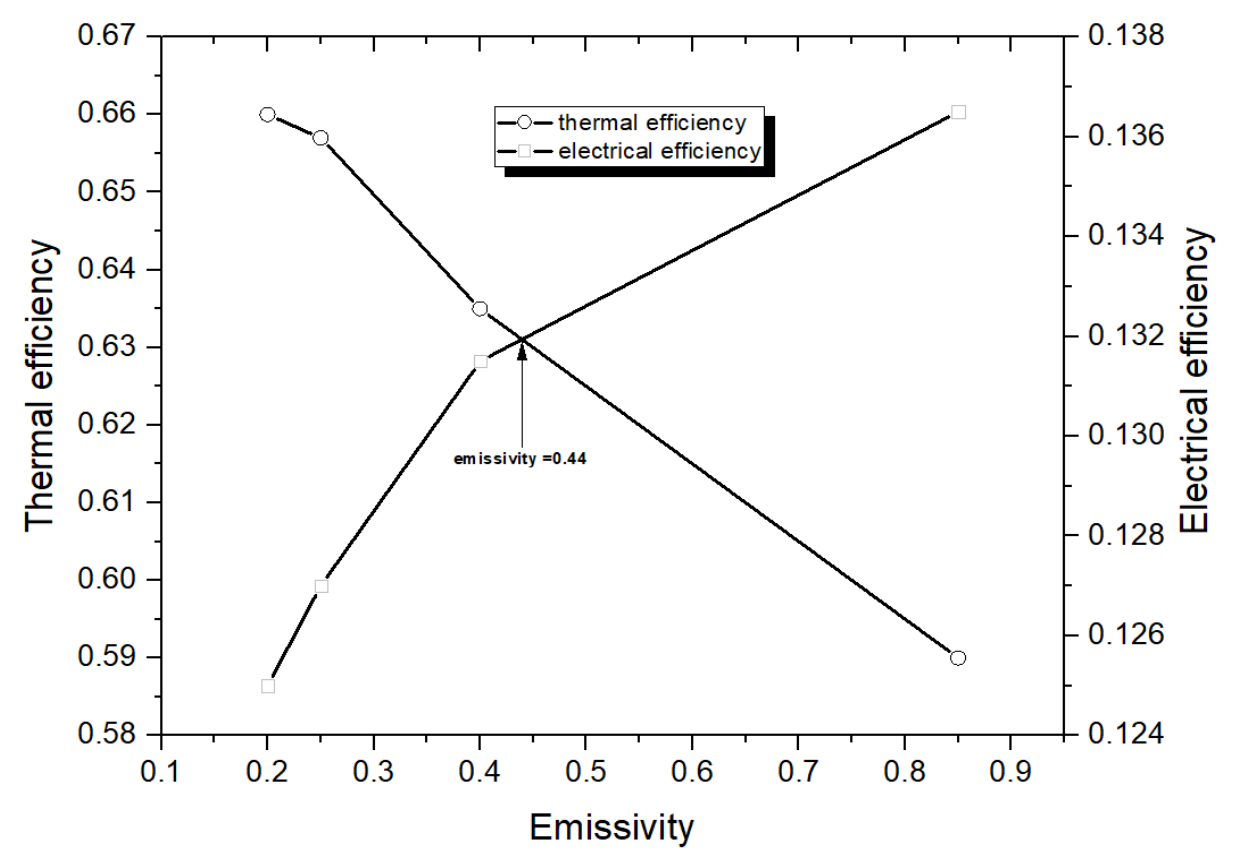

Figure 7: Thermal and electrical efficiencies as a function of emissivity. 
531 The thermal and electrical efficiency for the PVT sheet and tube without a specific optical coatings 532 (baseline) and for PVT with anti-reflective coatings are shown in table 2 and Fig.8. From these results, we 533 can observe that the enhancement in the solar transmission improves both thermal and electrical 534 efficiencies. The radiation transmission of the glass cover can be improved by applying an anti-reflective 535 coatings (ARC), which provide a better optical matching of the refractive indices between the glazing and 536 the static air layer, and between the glass cover and the surrounding air. On the other hand, a higher 537 reflective (without coating) leads to the increase in the thermal losses of the collector. As shown in Table 5382 and Fig.8, without ARC and no loss (i.e. temperature of fluid is equal to the ambient temperature) the 539 PVT collector exhibited $13.70 \%$ electrical efficiency and $58 \%$ thermal efficiency whereas those with 540 ARC exhibit $14.7 \%$ electrical and $61 \%$ thermal performances. The first order heat loss coefficient $\mathrm{C} 1$ 541 decrease from $6.8 \mathrm{~W} / \mathrm{m}^{2} \mathrm{~K}$ to $4.2 \mathrm{~W} / \mathrm{m}^{2} \mathrm{~K}$. This is a due that the use of anti-reflective coating can be 542 minimized the radiative heat loss

\begin{tabular}{|c|c|c|c|c|c|}
\hline Parameter & $\begin{array}{l}\text { PVT sheet } \\
\text { and tube } \\
\text { without } \\
\text { optical } \\
\text { coatings } \\
\text { (baseline) }\end{array}$ & $\begin{array}{l}\text { PVT sheet and } \\
\text { tube with Anti- } \\
\text { reflective coating }\end{array}$ & $\begin{array}{l}\text { PVT sheet and tube } \\
\text { with anti-reflective } \\
\text { and low-emissivity } \\
\text { coatings }\end{array}$ & $\begin{array}{l}\text { PVT sheet and tube } \\
\text { absorber with anti- } \\
\text { reflective and low-e } \\
\text { coating, assuming a } \\
\text { simple adhesive or } \\
\text { whole package } \\
\text { lamination } \\
\text { manufacturing process }\end{array}$ & $\begin{array}{l}\text { Advanced } \\
\text { channelled } \\
\text { PVT }\end{array}$ \\
\hline $\begin{array}{l}\text { Thermal conversion } \\
\text { factor for the no loss } \\
\left(\eta_{0}\right)\end{array}$ & $58 \%$ & $61 \%$ & $67 \%$ & $71 \%$ & $73 \%$ \\
\hline $\begin{array}{l}\text { linear heat loss } \\
\text { coefficient }(C 1) \mathrm{W} / \mathrm{m}^{2} \mathrm{~K}\end{array}$ & 6.8 & 4.2 & 3.9 & 3.9 & 3.9 \\
\hline $\begin{array}{c}\text { Temperature dependence } \\
\text { of heat losses }(\mathrm{C} 2) \\
\mathrm{W} / \mathrm{m}^{2} \mathrm{~K}\end{array}$ & 0.025 & 0.026 & 0.028 & 0.028 & 0.028 \\
\hline $\begin{array}{l}\text { Electrical conversion } \\
\text { factor for the no loss } \\
\left(\eta_{\text {elec }}\right)\end{array}$ & $13.70 \%$ & $14.70 \%$ & $14.25 \%$ & $15.10 \%$ & $15.40 \%$ \\
\hline $\begin{array}{l}\text { Linear temperature } \\
\text { dependence factor } \\
\qquad \mathrm{W} / \mathrm{m}^{2} \mathrm{~K}\end{array}$ & 0.5 & 0.45 & 0.45 & 0.45 & 0.45 \\
\hline
\end{tabular}

543 Table 1: Thermal and electrical efficiencies curves parameters for different considered PV-T collectors 


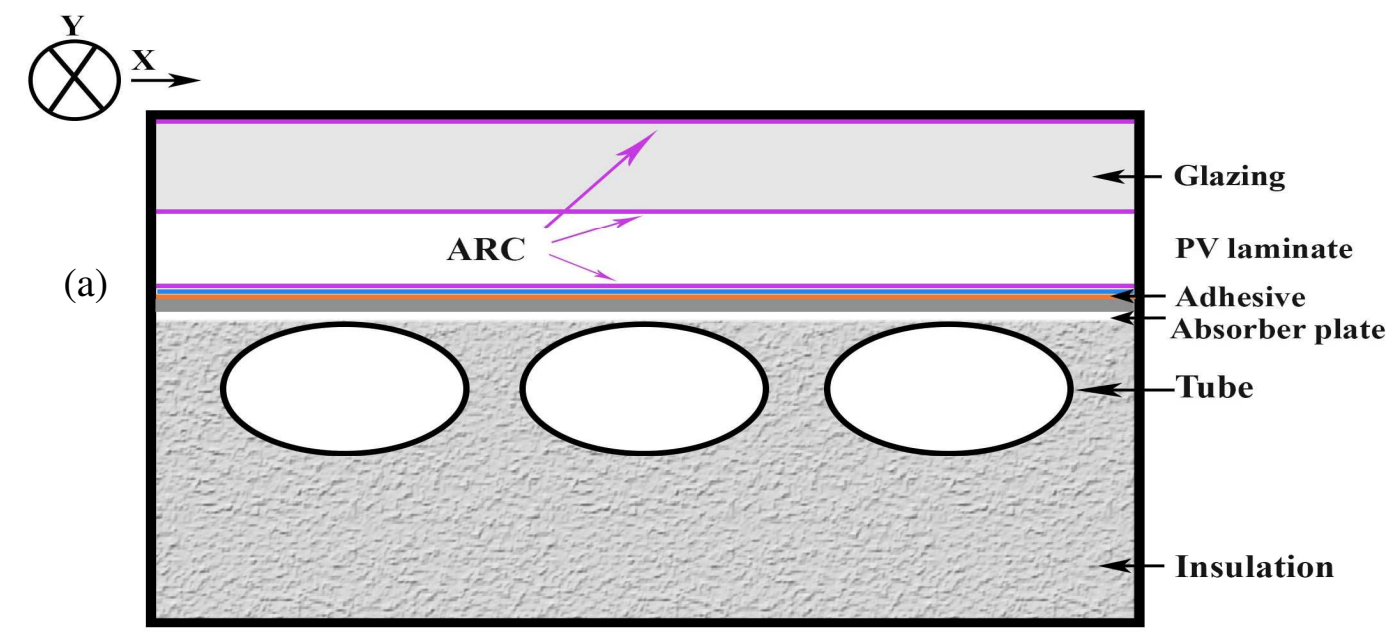

Figure 8-a: PVT sheet and tube collector with anti-reflective coatings

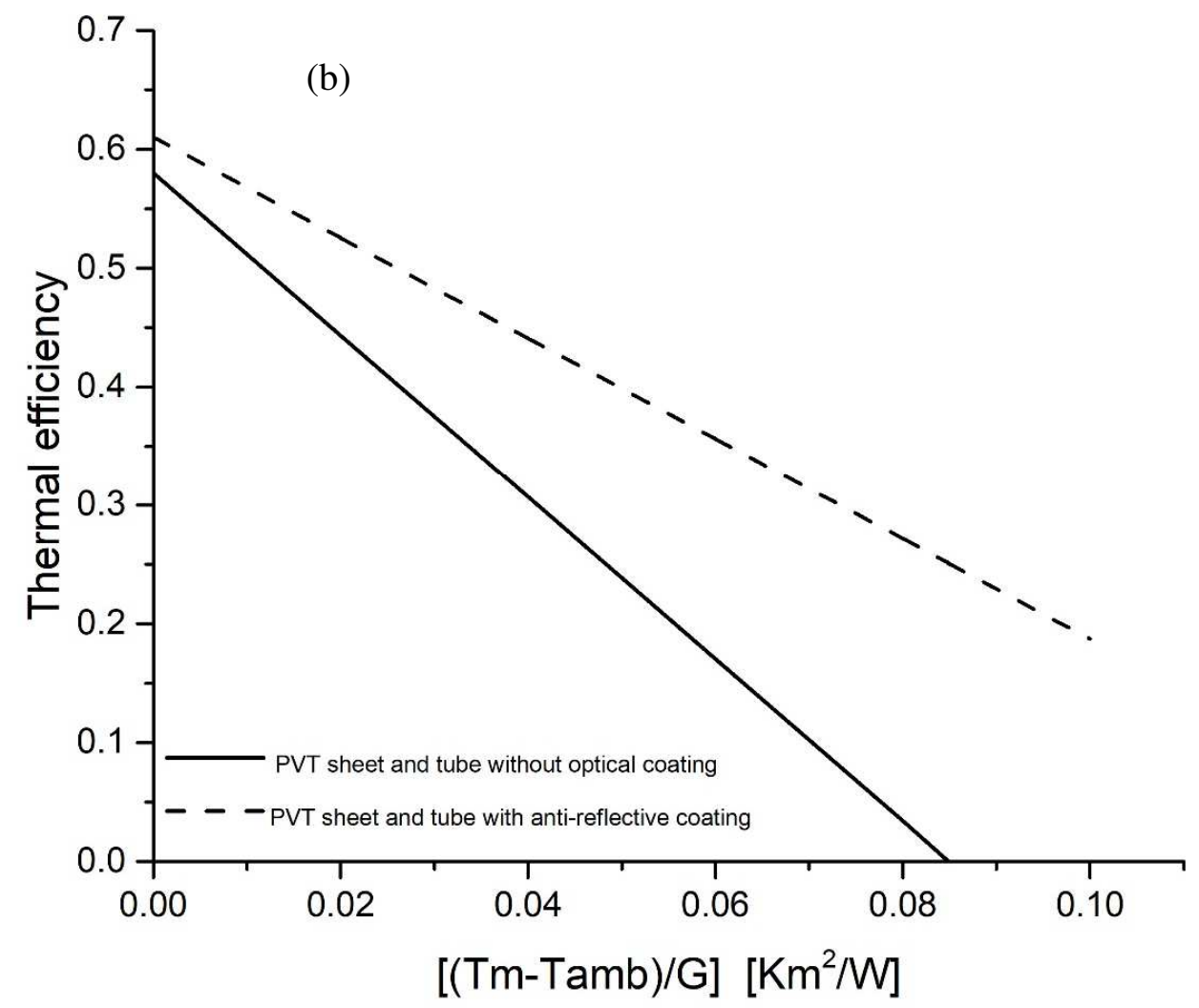




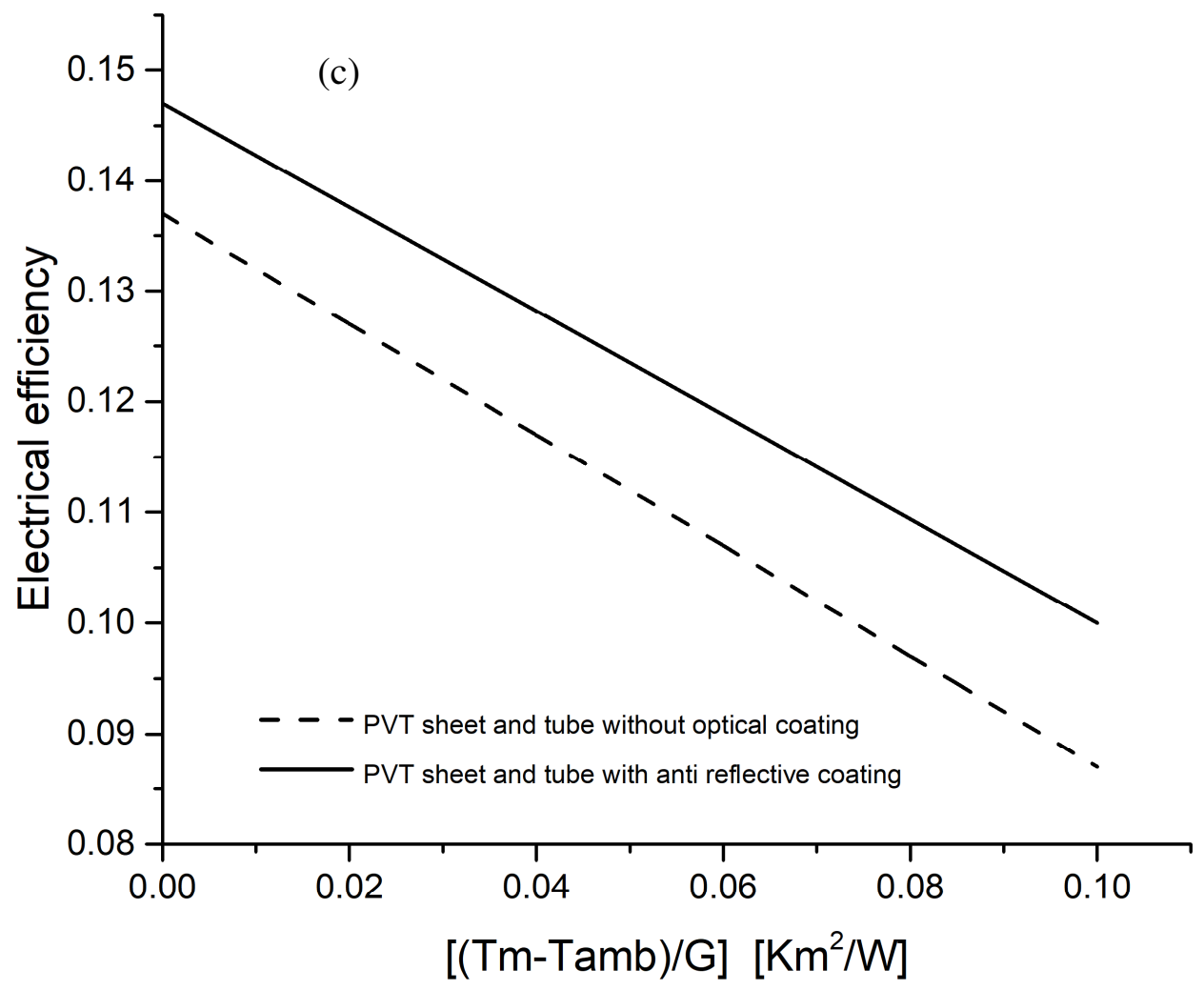

Figure 8-c: Electrical efficiency for a PV/T sheet-absorber without optical coatings, and for a PVT sheet and tube absorber with anti-reflective coating.

\section{- Anti-reflective and low-emissivity coating}

The thermal and electrical efficiency for the PVT sheet and tube without optical coatings (baseline) and for PVT with both anti-reflective and with a low emissivity coatings are shown in table 2 and Fig.9. From these results, we can note that for zero loss the PVT sheet and tube absorber with both anti-reflective and with a low emissivity provides the best thermal efficiency (67\%) among side-by- side PVT with antireflective (61\%) and PVT without optical coating (58\%). This is due to the fact that the infrared radiation losses can be reduced by applying a selective coating (low-e coating). As shown in in table 2 and Fig.9, without ARC and low emissivity, for the zero loss, the baseline PVT collector exhibits $13.7 \%$ electrical efficiency whereas those with ARC and low emissivity exhibit $14.25 \%$ performance. On the other hand, 

the electrical efficiency for the PVT sheet and tube absorber with both anti-reflective and with low 564 emissivity (14.25\%) were lower than for PVT sheet and tube with ARC and without low emissivity 565 (14.7\%). The use of low emissivity induces the augmentation in temperature of collector resulting the 566 drop in electrical efficiency.

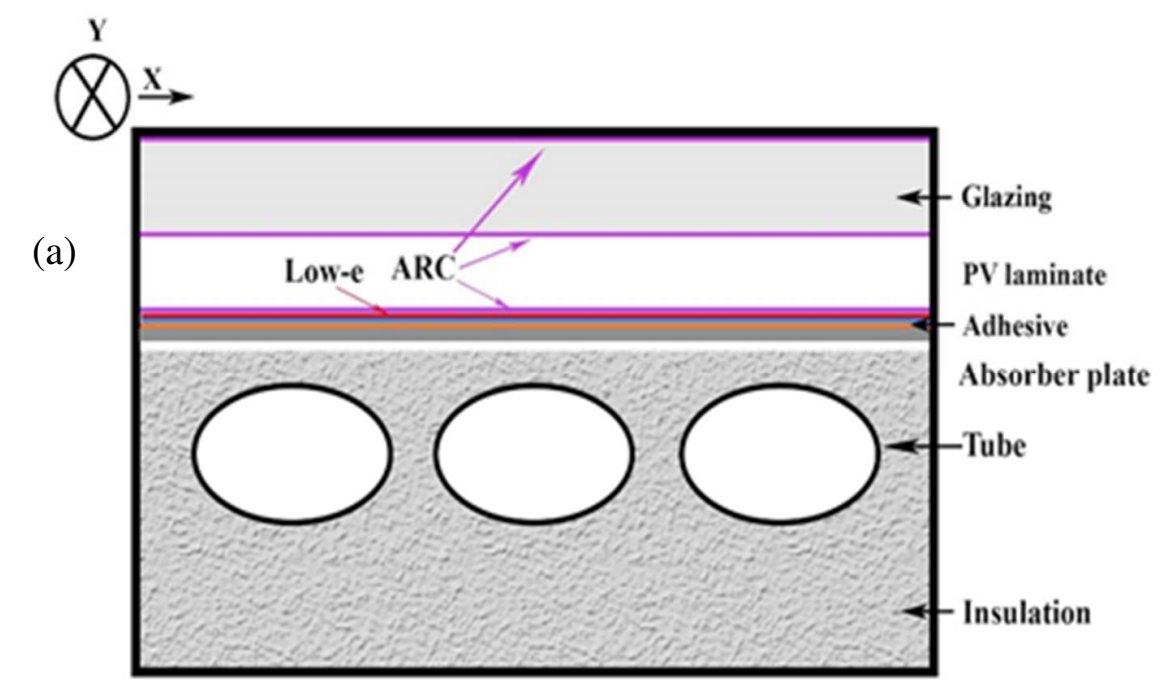




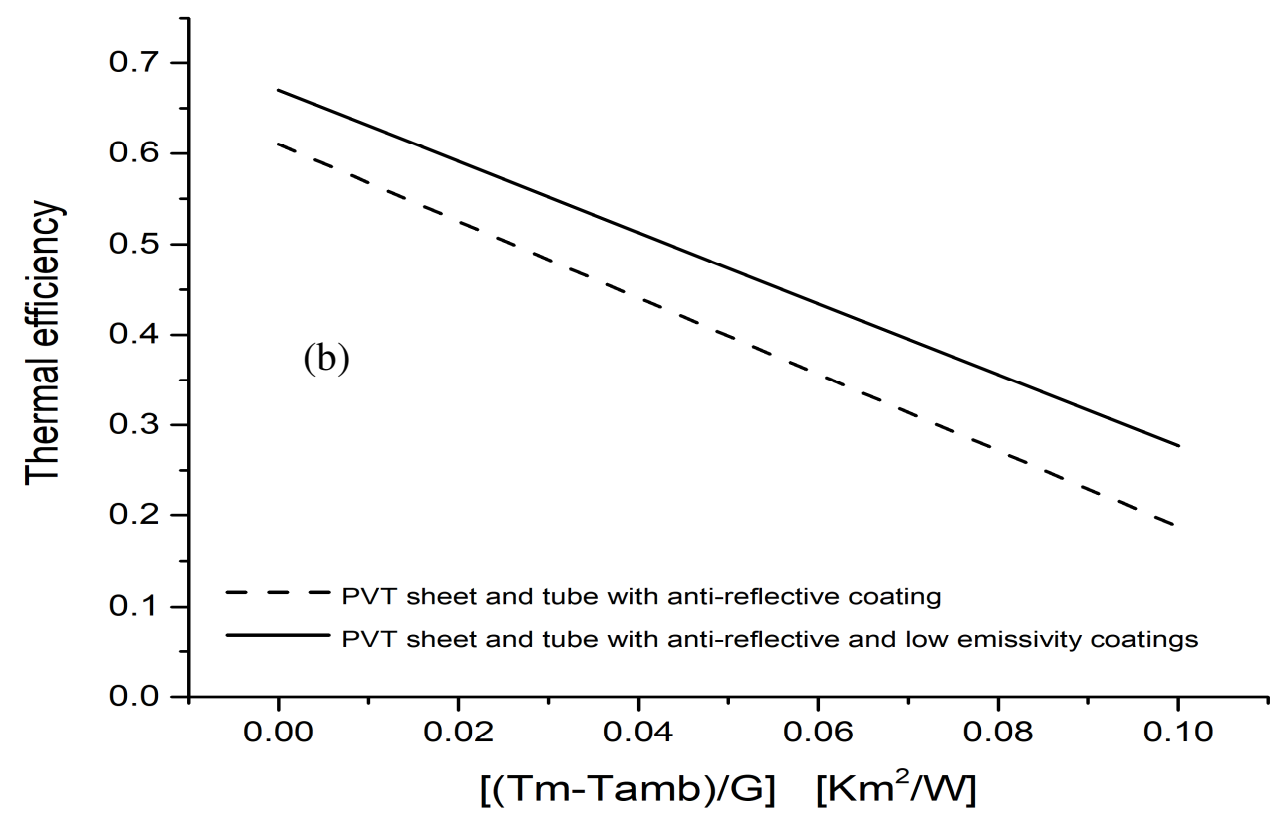

Figure 9-b: Thermal efficiency for a PV/T sheet-absorber with anti-reflective coatings, and for a PVT sheet and tube

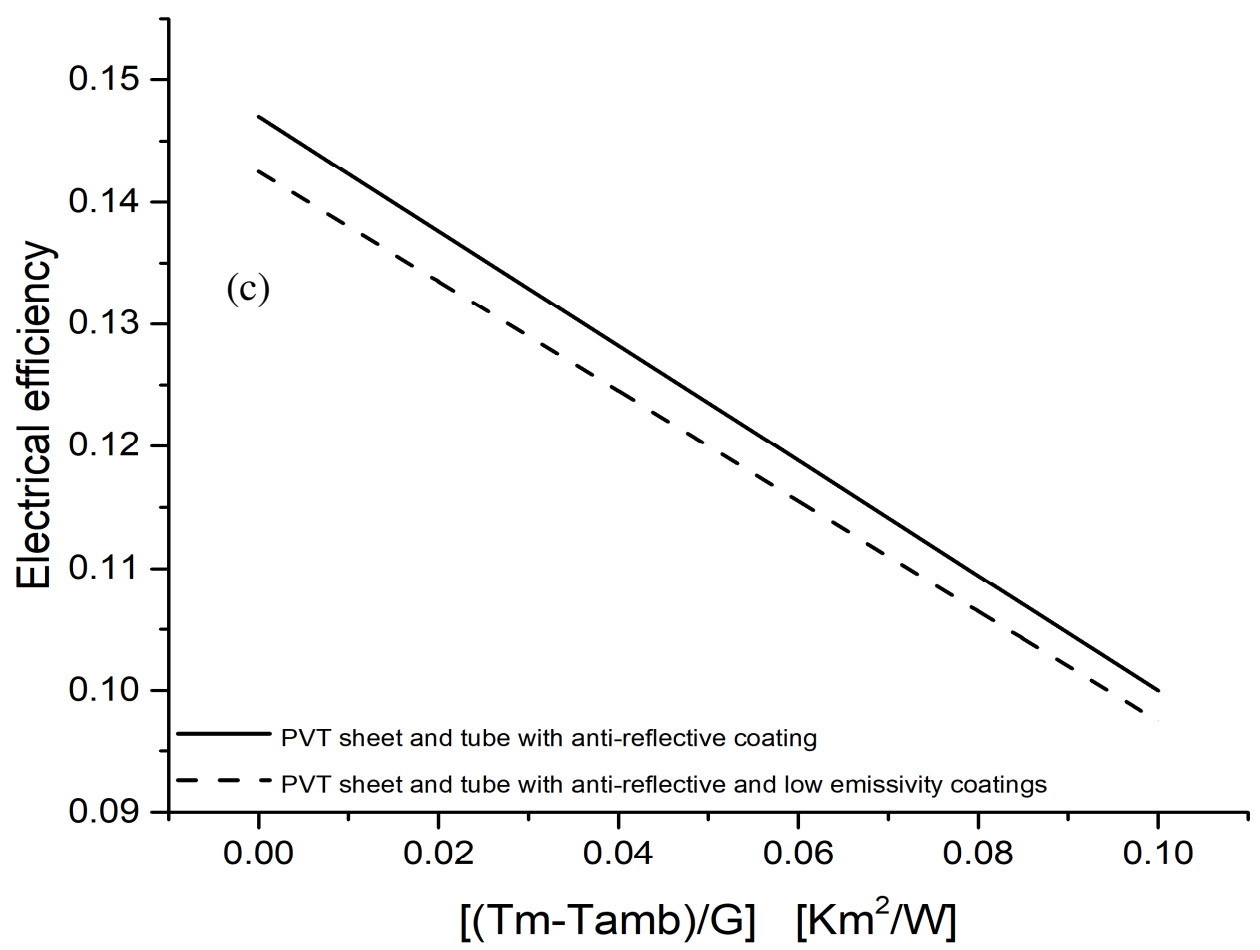


Figure 9-c: electrical efficiency for a PV/T sheet-absorber with anti-reflective coatings, and for a PVT sheet and tube absorber with both anti-reflective and with a low emissivity coating.

- The impact of thermal resistance thermal between the PV module and the absorber plate

As shown in Fig.10, the increase in conductive heat coefficient between the PV module and the absorber leads to a reduction in the temperature gradient between the PV module and the absorber. As shown in Table 2, with AR coatings and low emissivity PVT with a simple adhesive which corresponds to a heat transfer coefficient of a $45 \mathrm{~W} / \mathrm{m}^{2} \mathrm{~K}$ exhibited $14.25 \%$ electrical and $67 \%$ thermal performances for the no loss whereas those PVT with advanced encapsulation of components during the lamination manufacturing phase exhibited $15.10 \%$ electrical and $71 \%$ thermal performances. The advantage of this method is to greatly reduce the contact resistance $\left(700 \mathrm{~W} / \mathrm{m}^{2} \mathrm{~K}\right)$ between the photovoltaic and thermal layers. The enhancement of the conductive heat transfers between the PV module and the absorber results in a smaller temperature gradient and therefore a lower PV cell temperature and higher absorber temperature. As a consequence, it improved both thermal and electrical efficiencies, as shown in table 2 and Fig.11

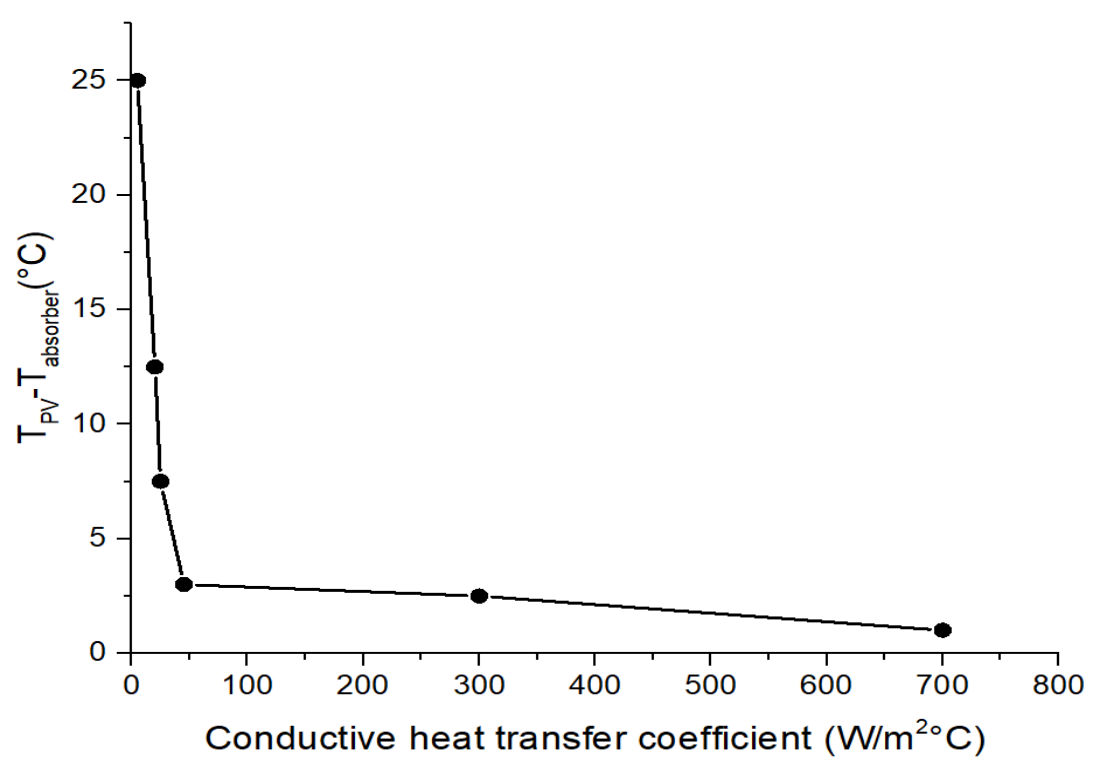

Figure 10: Temperature difference between PV module and absorber layers versus conductive heat coefficient. 


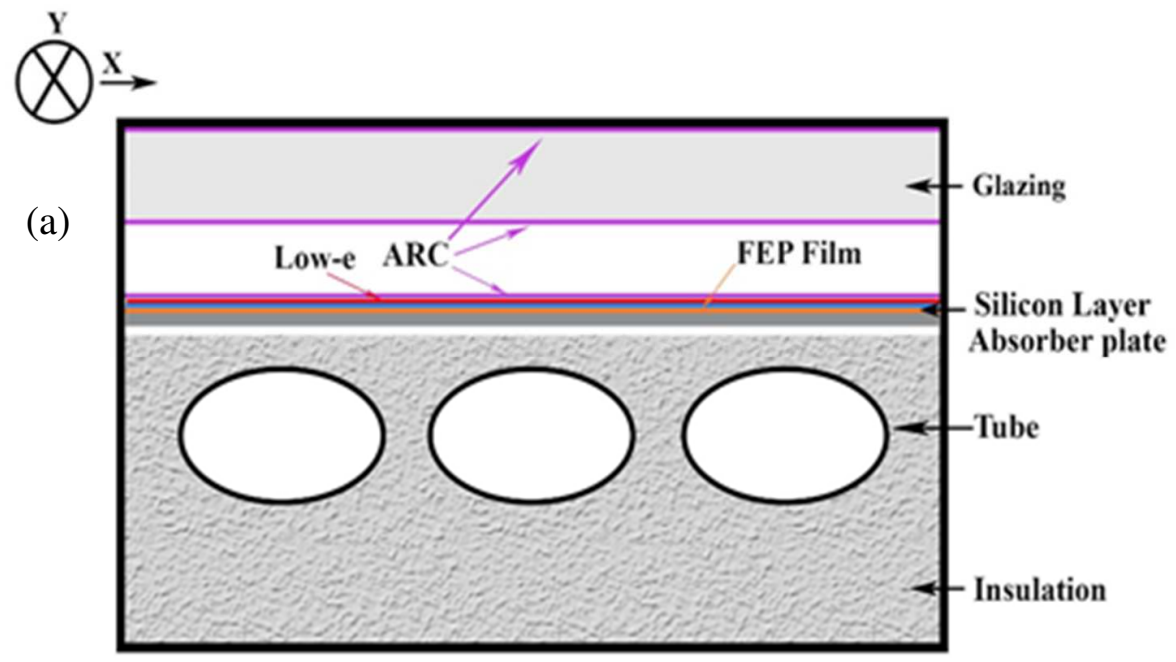

Figure 11-a: PVT sheet and tube collector with both anti-reflective and with a low emissivity coating and whole package lamination manufacturing process.

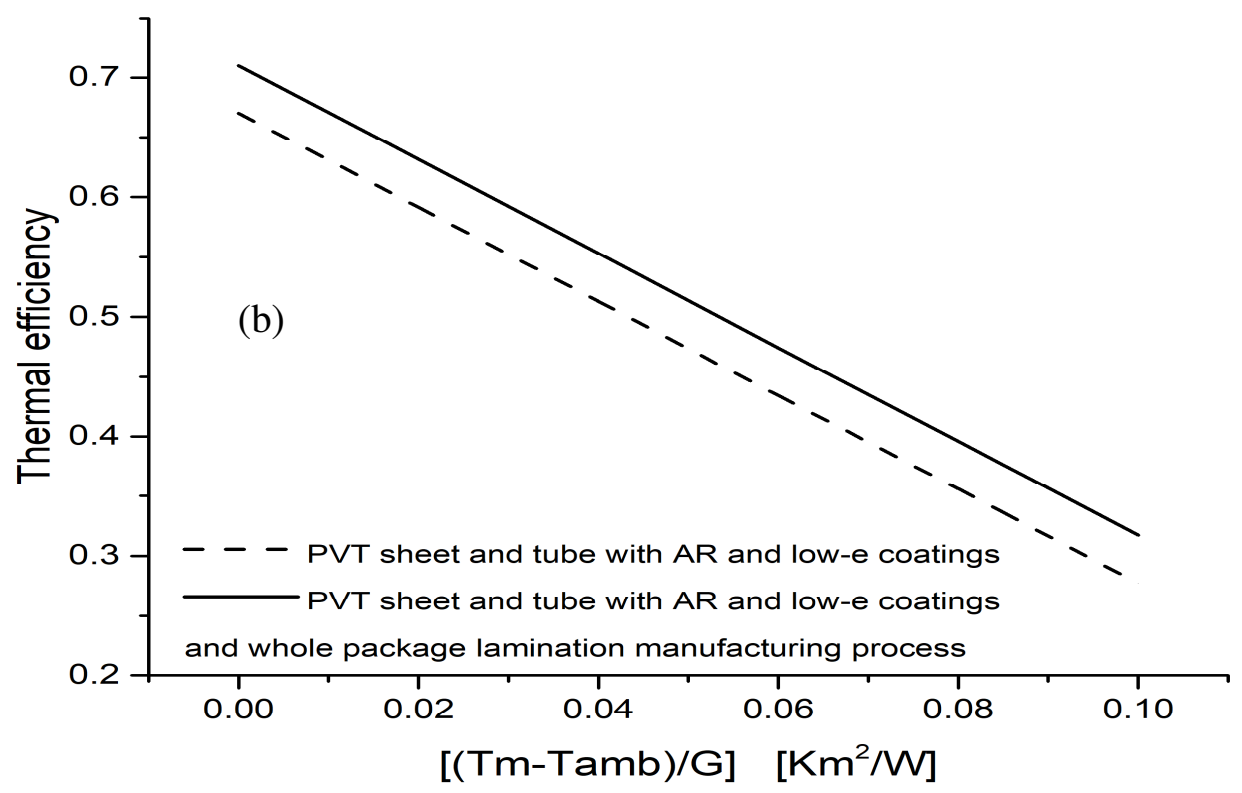

Figure 11-b: Predicted thermal efficiencies of a PVT sheet and tube absorber with anti-reflective and low-e coating, assuming a simple adhesive or whole package lamination manufacturing process. 


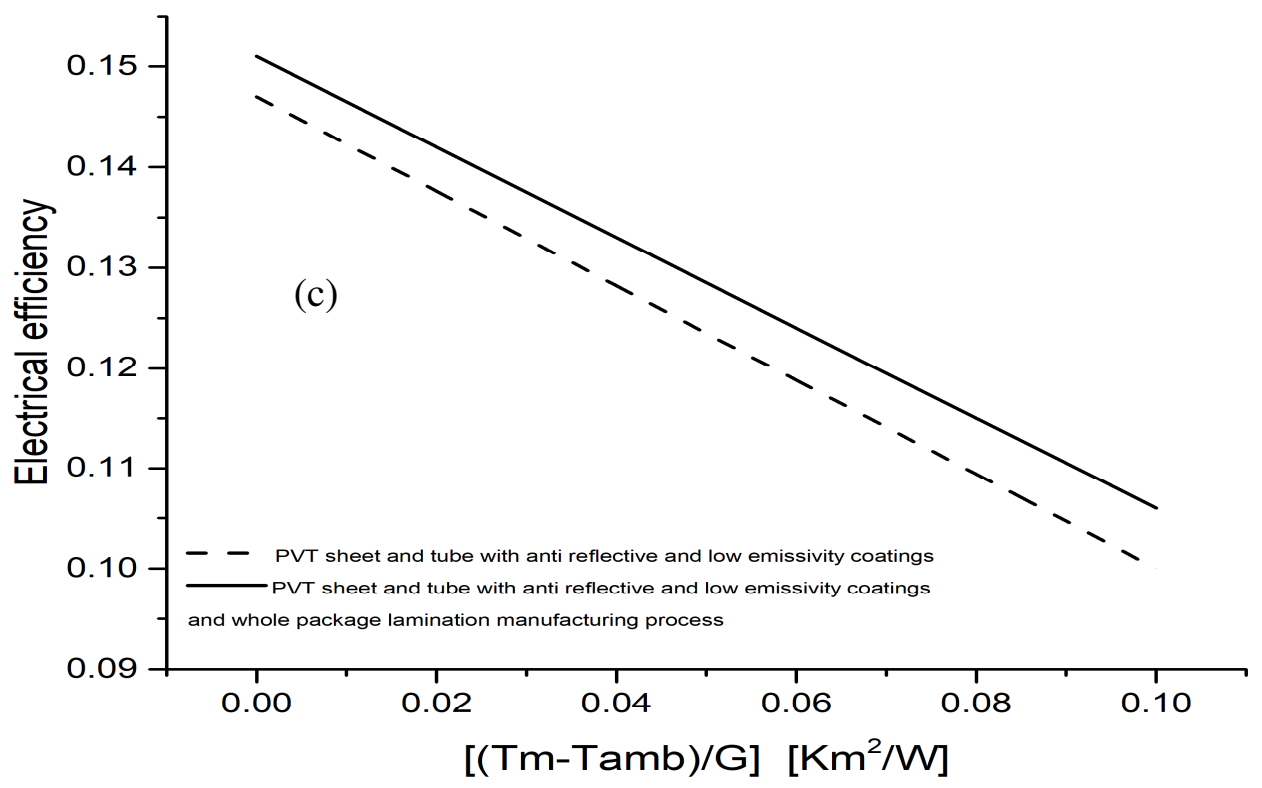

598

Figure 11-c: Predicted electrical efficiency of a PVT sheet and tube absorber with anti-reflective and low-e coating, assuming a simple adhesive or whole package lamination manufacturing process. cooling fluid

603 Efficient heat transfer is required between the absorber plate, absorber pipes, and then from the pipes to 604 the cooling fluid. As shown in table 2 and Fig.12, a PVT with a sheet and tube with anti-reflective, low-e 605 coatings and whole packing lamination manufacturing process collector exhibited $15.10 \%$ electrical and $60671 \%$ thermal performances whereas those with channelled absorber exhibited $15.40 \%$ electrical and $73 \%$ 607 thermal performances, for the no loss. This is due to enhanced tube fin efficiency and improved 608 conduction between the plate absorber and the pipes. 


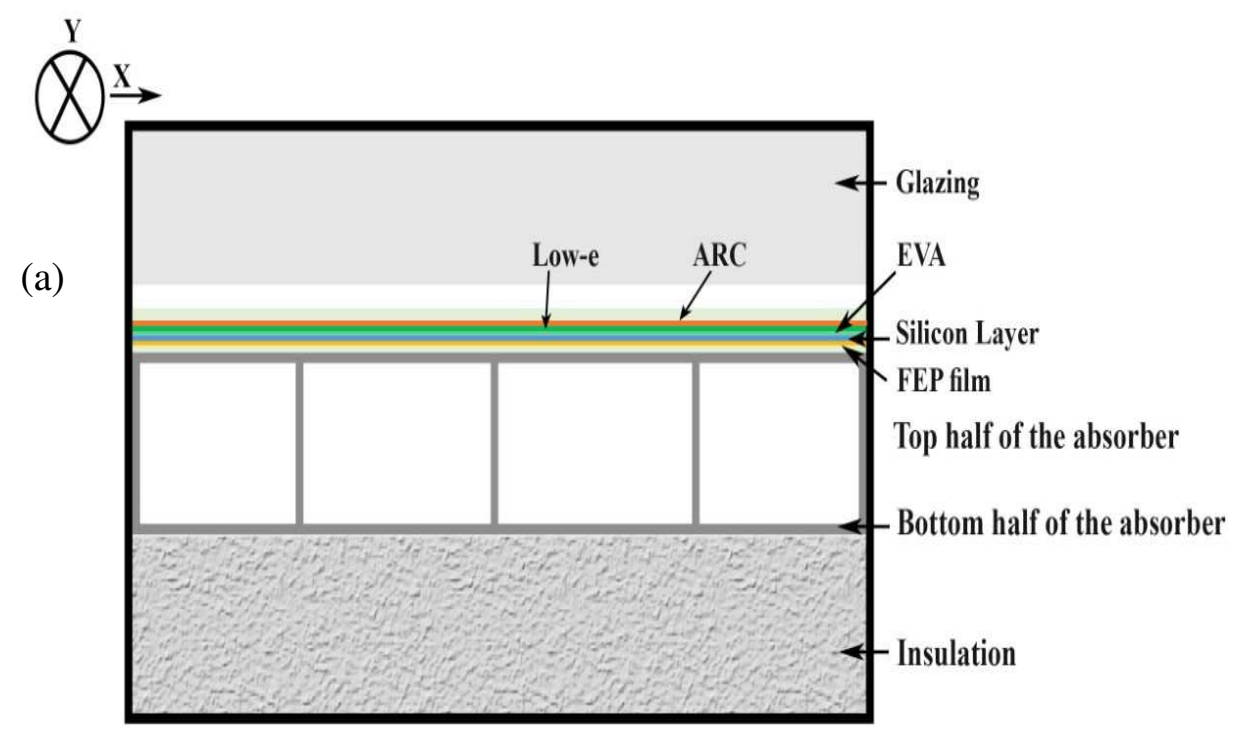

609

610 Figure 12-a: The advanced PVT channelled collector considered in the present study

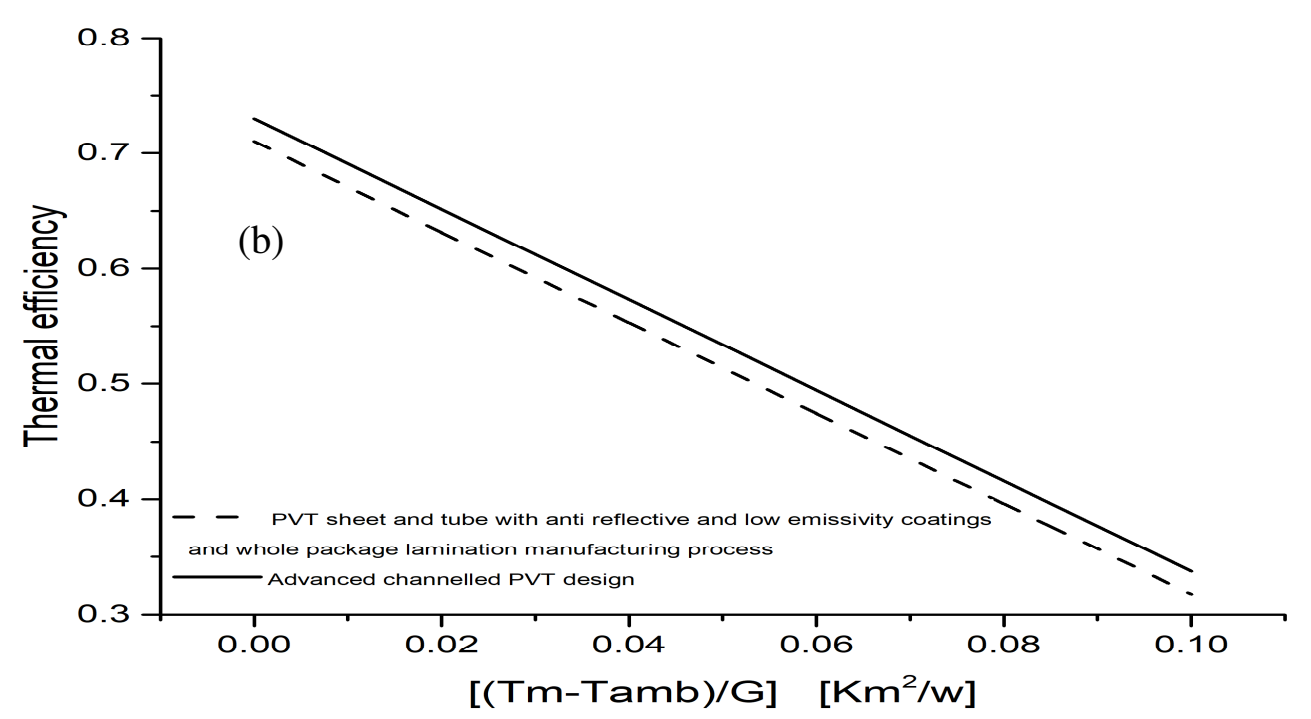

613 Figure 11-b: Predicted thermal efficiency of a PVT module with a sheet and tube absorber compared to one with a 614 channelled absorber. Both configurations include anti-reflective and low-e coatings, and assume whole package 615 lamination. 


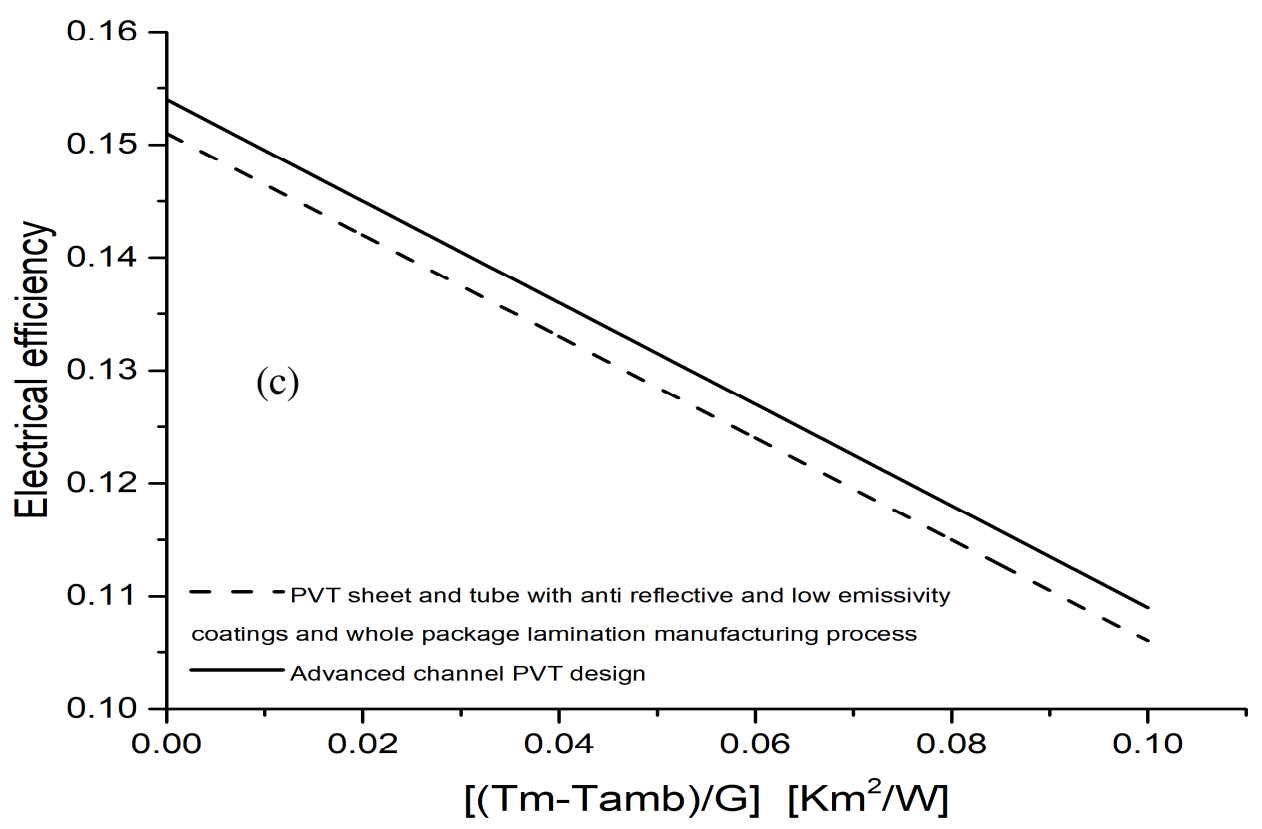

616

617 Figure 11-c: Predicted electrical efficiency of a PVT module with a sheet and tube absorber compared to one with a

618 channelled absorber. Both configurations include anti-reflective and low-e coatings, and assume whole package 619 lamination.

\subsection{Temperature distributions}

The steady state temperature fields are calculated under nominal environmental conditions for inlet fluid temperature $\left(20^{\circ} \mathrm{C}\right)$, solar radiation $\left(800 \mathrm{~W} / \mathrm{m}^{2}\right)$, ambient temperature $\left(20^{\circ} \mathrm{C}\right)$ and wind speed $(1 \mathrm{~m} / \mathrm{s})$. The photovoltaic layer and fluid temperature fields of the PVT sheet and tube without the coating collector and advanced channeled PVT design with optical coatings are presented in Fig. 12. Under the same conditions, higher PV temperatures are attained for the sheet and tube (between $65.7^{\circ} \mathrm{C}$ to $65.46^{\circ} \mathrm{C}$ ) than the PVT with channel design (between $51.98^{\circ} \mathrm{C}$ to $51.82^{\circ} \mathrm{C}$ ). The fluid temperatures for the two configurations increase from inlet to outlet with similar trends, although steeper gradients are observed for the channel design. From inlet to outlet, the fluid temperatures rise from $20^{\circ} \mathrm{C}$ to $42^{\circ} \mathrm{C}$ for the sheet and tube collector (C1) and from $20^{\circ} \mathrm{C}$ to $48^{\circ} \mathrm{C}$ for PVT with channels collector (C2). An enhancement of heat transfers between the photovoltaic module and the absorber is obtained due to the advanced laminated technique (C2), allowing Low-emissivity, ARC, solar cell, EVA and fluorinated ethylene propylene (FEP) lamination directly onto the absorber $(\mathrm{C} 2)$. This results in a lower temperature gradient

633 between the PV module and the absorber and therefore in a lower PV-cell temperature and a higher absorber temperature. Thus, good thermal contact between the absorber plate and the fluid provides 
higher fluid temperatures. Considering the temperature gradient between the photovoltaic cells and water, it is therefore confirmed that the advanced channeled PVT design with optical coatings operates at higher fluid temperatures and lower photovoltaic cell temperature. This consequently offers better electrical and thermal efficiencies.

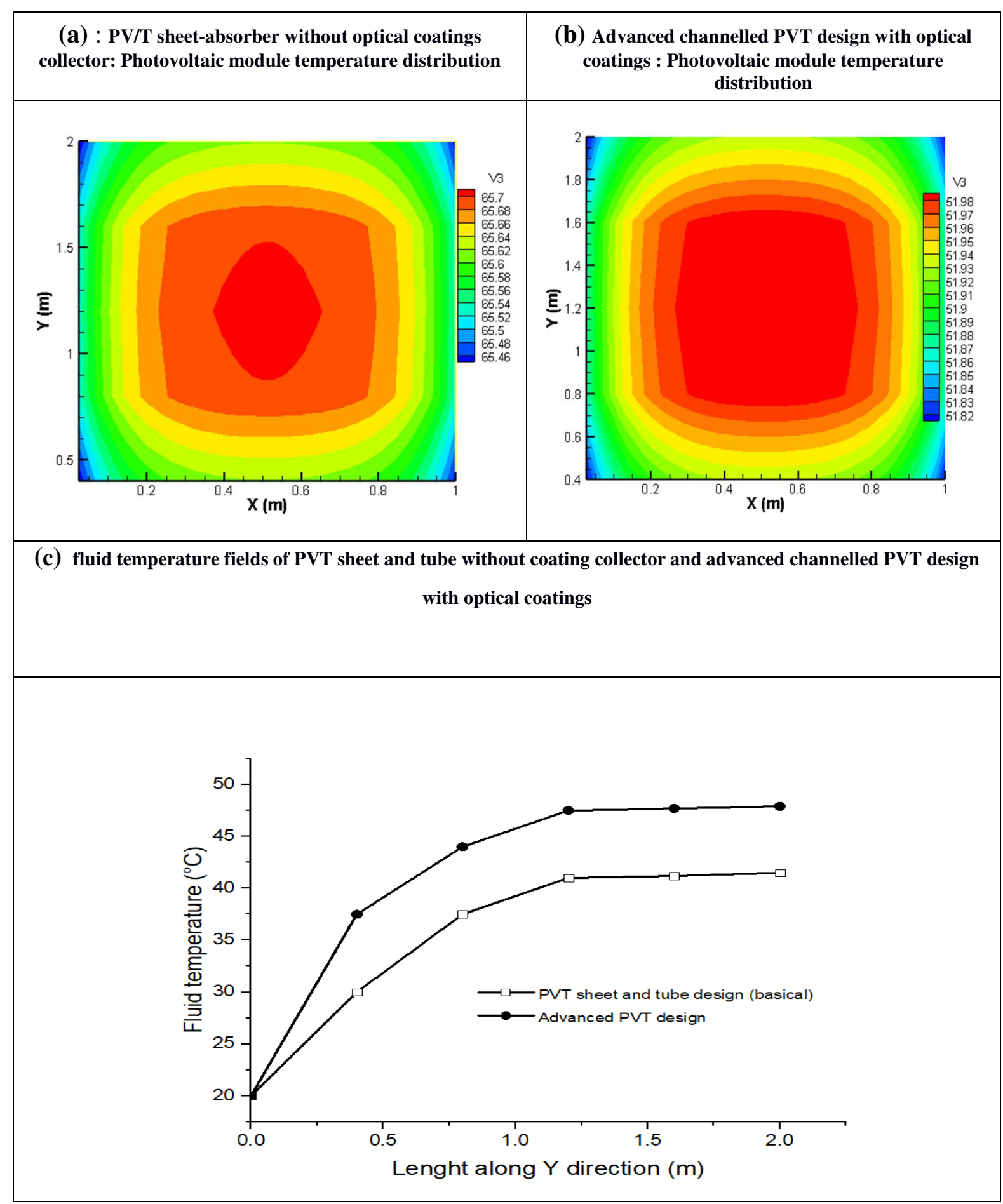


639
Figure 12: The photovoltaic layer and fluid temperature fields of PVT sheet and tube without coating collector and advanced channelled PVT design with optical coatings

In this work, a novel PVT collector design is proposed as well as a 2D modeling approach. The detailed PVT numerical model is developed and validated with experimental results available in the literature [4445]. It allows deepening the analysis and understanding of the impact of new proposed changes of the new PVT compared to the basic PVT collector (sheet and tube heat exchanger). The effects of the optical coating, the thermal resistance between the photovoltaic and absorber plate, the contact area between the absorber and the cooling fluid are investigated and analyzed. The main findings are summarized as follows:

- The addition of an anti-reflective coating on the photovoltaic module leads to an increase of both the electrical and thermal performances.

- The thermal efficiency can be improved by the addition of a low-e coating, albeit at the detriment of a reduced electrical efficiency. An optimal value of 0.44 for the emissivity was determined for both the electrical and thermal efficiencies.

- The conductive heat transfers between the PV module and the thermal absorber is enhanced. As a consequence, lower temperature gradient and therefore lower PV cell 

of the thermal and electrical efficiencies.

Consequently, the proposed PVT collector design provides the highest fluid temperature and the lowest photovoltaic module temperature compared to the basic one (PVT with sheet and tube absorber). The novel PVT provides $73 \%$ and $15.4 \%$ electrical and thermal efficiencies, respectively under no loss and standard test conditions (inlet fluid temperature: $20^{\circ} \mathrm{C}$; solar radiation: $800 \mathrm{~W} / \mathrm{m}^{2}$; ambient temperature: $20{ }^{\circ} \mathrm{C}$; and wind speed: $1 \mathrm{~m} / \mathrm{s}$ ).

\section{Acknowledgements}

The authors thank the French Environment and Energy Management Agency (ADEME) and Fédération Nationale de l'Energie Solaire (FedESol) FR CNRS 3344 for their support.

\section{References}

[1] Daher D.H, Gaillard L, Amara M, Ménézo C. Impact of tropical desert maritime climate on the performance of a PV grid-connected power plant. Renewable Energy $125 ; 2018: 729-737$

[2] Garg H.P, Ahhikari R.S. Conventional hybrid photovoltaic/thermal (PV/T) air heating collector: steady-state simulation. Renewable Energy $1997 ; 11: 363-85$.

[3] Rejeb O, Dhaou H, Jemni A. Parameters effect analysis of a photovoltaic thermal collector: Case study for climatic conditions of Monastir, Tunisia. Energy Conversion and Management 2015; 89: 409419.

[4] Bergene T, Lovvik O.M. Model calculations on a flat-plate solar heat collector with integrated solar cells. Solar Energy $1995 ;$ 55:453-462.

[5] Touafek K, Khelifa A, Adouane M. Theoretical and experimental study of sheet and tubes hybrid PVT collector. Energy Conversion Manage 2014; 80:71-7.

[6] Zondag H.A, De Vries D.W, Van Helden W.G.J, Van Zolingen R.J.C, Van Steenhoven A.A. The thermal and electrical yield of a PV-thermal collector. Solar Energy 2002;72(2):113-28. 
[7] Lalovic B. A hybrid amorphous silicon photovoltaic and thermal solar collector. Solar Cells 19861987; 19:131-8.

[8] Jakhar S, Soni M.S. Experimental and theoretical analysis of glazed tube-and sheet photovoltaic/thermal system with earth water heat exchanger cooling. Energy Conversion and Management 2017; 153: 576-588.

[9] Souliotis M., Arnaoutakis N., Panaras G., Kavga A., Papaefthimiou S. Experimental study and life cycle assessment (LCA) of hybrid photovoltaic/thermal (PV/T) solar systems for domestic applications. Renewable Energy 2018;126: 708-723.

[10] Salari A., Fard A. H.. A numerical study of dust deposition effects on photovoltaic modules and photovoltaic-thermal systems, Renewable Energy 2019: 135: 437-449.

[11] Fraisse G, Ménézo C, Johannes K. Energy performance of water hybrid PV/T collectors applied to combined systems of direct solar floor type. Solar Energy 2007; 81(11):1426-38.

[12] Ramos A, Chatzopoulou M.A, Guarracino I, Freeman J, Markides C.N. Hybrid photovoltaic-thermal solar systems for combined heating, cooling and power provision in the urban environment. Energy Conversion and Management 2017.

[12] Ramos A, Chatzopoulou MA, Guarracino I, Freeman J, Markides CN. Hybrid photovoltaic-thermal solar systems for combined heating, cooling and power provision in the urban environment. Energy Conversion and Management 2017; 150:838-50.

[13] Sandnes B, Rekstad J. A photovoltaic/thermal (PV/T) collector with a polymer absorber plate: experimental study and analytic model. Solar Energy 2002; 72(1):63-73.

[14] Salem M.R., R.K. Ali, Elshazly K.M, Experimental investigation of the performance of a hybrid photovoltaic/thermal solar system using aluminium cooling plate with straight and helical channels. Solar Energy 2017;157: 147-156.

[15] Yang X, Sun L, Yuan Y, Zhao X, Cao X. Experimental investigation on performance comparison of PV/T-PCM system and PV/T system. Renewable Energy $2018 ; 119$ :152-9.

[16] Malvi C.S, Dixon-Hardy D.W, Crook R. Energy balance model of combined photovoltaic solarthermal system incorporating phase change material. Solar Energy $2011 ; 85: 1440-6$.

[17] Emam M, Ookawara S, Ahmed M. Performance study and analysis of an inclined concentrated photovoltaic-phase change material system. Solar Energy $2017 ; 150: 229-45$.

[18] Hasan A, Sarwar J, Alnoman H, Abdelbaqi S. Yearly energy performance of a photovoltaic-phase change material (PV-PCM) system in hot climate. Solar Energy $2017 ; 146: 417-29$.

[19] Ahmed O.K., Mohammed Z.A. Influence of porous media on the performance of hybrid PV/Thermal collector, Renewable Energy 2017 ;112 :378-387.

[20] Ahmed O.K, Hamada K.I, Salih A.M. Enhancement of the performance of Photovoltaic/Trombe wall system using the porous medium: Experimental and theoretical study, Energy 2019 ;171: 14-26. 
[21] Bakar M.N. A, Othman M, Din M.H, Manaf N. A, Jarimi H. Design concept and mathematical model of a bi-fluid photovoltaic/thermal (PV/T) solar collector.Renewable Energy 2014;67:153-64.

[22] Jarimi H, Bakar M.N.A, Othman M, Din M.H. Bi-fluid photovoltaic/thermal (PV/T) solar collector: experimental validation of a 2-D theoretical model. Renewable Energy 2016 ;85:1052-67.

[23] Su D, Jia Y, Huang X, Alva G, Tang Y, Fang G. Dynamic performance analysis of photovoltaic thermal solar collector with dual channels for different fluids. Energy Conversion and Management 2016 ;120:13-24.

[24] Assoa Y.B, Menezo C, Fraisse G, Yezou R, Brau J. Study of a new concept of photovoltaic thermal hybrid collector, Solar Energy 812007 ;81: 1132-1143.

[25] Daghigh R, Khaledian Y. Design and fabrication of a bi-fluid type photovoltaicthermal collector. Energy 2017;135;15::112-27.

[26] Assoa Y.B., C. Ménézo C. Dynamic study of a new concept of photovoltaic-thermal hybrid collector, Solar Energy $2014 ; 107$ : 637-652.

[27] Zondag H.A. Flat-plate PV-Thermal collectors and systems: a review. Renew Sustain Energy Rev 2008;12(4):891-959.

[28] Dupeyrat, P. Experimental Development and Simulation Investigation of a Photovoltaic-Thermal Hybrid Solar Collector 2011; INSA Lyon, Lyon.

[29] Pei G, Fu H, Zhu H, Jie J. Performance study and parametric analysis of a novel heat pipe PV/T system. Energy 2012; 37:384-95

[30] Santbergen R, Rindt C.C.M, Zondag H.A, van Zolingen R.J.C. Detailed analysis of the energy yield of systems with covered sheet-and-tube PVT collectors. Solar Energy 2010; 84:867-78.

[31] Lämmle M, Kroyer T, Fortuin S, Wiese M, Hermann M. Development and modelling of highlyefficient PVT collectors with low-emissivity coatings. Solar Energy 2016; 130:161-73.

[32] Florschuetz L.W. Extension of the Hottel-Whiller Model to the analysis of combined photovoltaic/ thermal flat plate collectors. Solar Energy 1979 ;22:361-6.

[33] Chow TT. Performance analysis of photovoltaic-thermal collector by explicit dynamic model. Solar Energy $2003 ; 75: 143-52$.

[34] Patankar S.V. Numerical heat transfer and fluid flow. Washington, DC : Hemisphere Publishing Corporation ; 1980.

[35] Domenech-Garret J.L. Cell behaviour under different non-uniform temperature and radiation combined profiles using a two dimensional finite element model. Solar Energy $2011 ; 85$ :256-64

[36] Ahmed M, Radwan A. Performance evaluation of new modified low-concentrator polycrystalline silicon photovoltaic/thermal systems. Energy Convers Manage 2017 ;149:593-607. 
[37] Siddiqui M.U, Arif F.M. Electrical, thermal and structural performance of a cooled PV module: transient analysis using a multiphysics model. Applied Energy $2013 ; 112: 300-12$

[38] Kumar S, Sharma V.B, Kandpal T.C, Mullick S.C. Wind induced heat losses from outer cover of solar collectors. Renew Energy $1997 ; 10$ :613-6.

[39] Duffie JA, Beckman WA. Solar engineering of thermal processes. New Jersey : Wiley; 2006.

[40] Swinbank WC, Roy QJ. Long-wave radiation from clear skies. Metereol Soc $1963 ; 89: 339$.

[41] Hollands K.G.T, Unny T.E, Raithby G.D, Konicek L. Free convective heat transfer across inclined air layers. J Heat Transfer ASME Trans 1976 ;98:189-93.

[42] Evans DL. Simplified method for predicting photovoltaic array output. Sol Energy $1981 ; 27: 555-6$.

[43] Bejan A. Heat transfer. New York : Wiley; 1993.

[44] Bhattarai S, Ohb J.H, Euh S.H, Kaflea G.K, Kima G.H. Simulation and model validation of sheet and tube type photovoltaic thermal solar system and conventional solar collecting system in transient states. Solar Energy Materials and Solar Cells 2012; 103:184-93.

[45] Sardarabadi M, Fard M.P, Heris S.Z. Experimental investigation of the effects of silica/water nanofluid on PV/T (photovoltaic thermal units). Energy 2014; 66:264-72. 